\title{
TAXONOMIC REVIEW OF THE GENUS LUCIOBARBUS HECKEL, 1843 (ACTINOPTERYGII, CYPRINIDAE) FROM NORTHWESTERN MOROCCO WITH THE DESCRIPTION OF THREE NEW SPECIES
}

\author{
Miriam Casal-Lopez ${ }^{1}$, Silvia Perea ${ }^{1}$, Ahmed Yahyaoui $^{2} \&$ Ignacio Doadrio $^{1 \star}$ \\ 'Biodiversity and Evolutionary Group. National Museum of Natural Sciences. \\ CSIC. C/ José Gutiérrez Abascal, 2. 28006. Madrid. Spain \\ MC-L: urn:Isid:zoobank.org:author:84DEBB1B-A34C-412A-B03B-C3492A4E59BE \\ SP: urn:Isid:zoobank.org:author:75C3112F-5BE9-4512-A9DB-DDA2A10497C7 \\ ID: urn:Isid:zoobank.org:author:1514FE9E-2AA2-46D1-BB43-51F5E8EF1566
}

${ }^{2}$ Laboratory of Zoology and General Biology, Faculty of Sciences, Mohammed V University. B.P. 1014. Rabat. Morocco urn:Isid:zoobank.org:author:EA344560-E0FA-4D5D-A51C-23771D124D4B

\section{ABSTRACT}

* Corresponding author: doadrio@mncn.csic.es

The genus Luciobarbus in Morocco presents high diversification, in contrast to the generally impoverished freshwater fish fauna from North Africa. Within Morocco the northern area is one of the least studied territories, due to both its historical background and the limited accessibility of many regions. Previous phylogenetic studies identified Luciobarbus populations that are morphologically and genetically differentiated, to the same extent as others already recognized as separate species. The aim of this work is to describe these populations as distinct species, based on morphological, meristic, and genetic traits.

urn:Isid:zoobank.org:pub:8FC4B423-104C-4097-A468-ED3D2664A15A

Key words: Cyprinidae; Luciobarbus; taxonomic review; new species; Morocco.

\section{RESUMEN}

Revisión taxonómica del género Luciobarbus Heckel, 1843 (Actinopterygii, Cyprinidae) del noroeste de Marruecos con la descripción de tres nuevas especies

En Marruecos el género Luciobarbus está altamente diversificado, en comparación con la empobrecida fauna de peces de agua dulce del norte de África. Dentro de Marruecos la región norte es una de las áreas menos estudiadas, por motivos históricos y también por la poca accesibilidad en algunas de sus regiones. Los estudios filogenéticos previos para esta área han señalado la existencia de poblaciones pertenecientes al género Luciobarbus tan diferenciadas morfológica y genéticamente como otras que ya habían sido reconocidas como diferentes especies. En este trabajo describimos estas poblaciones como diferentes taxa, en base a caracteres morfológicos, merísticos y genéticos.

Palabras clave: Cyprinidae; Luciobarbus; revisión taxonómica; nuevas especies; Marruecos.

\section{Recibido/Received: 06/04/2015; Aceptado/Accepted: 08/05/2015; Publicado en línea/Published online: 19/08/2015}

Cómo citar este artículo/Citation: Casal-Lopez, M., Perea, S., Yahyaoui, A. \& Doadrio, I. 2015. Taxonomic review of the genus Luciobarbus Heckel, 1843 (Actinopterygii, Cyprinidae) from northwestern Morocco with the description of three new species. Grael/sia, 71(2): e027. http://dx.doi.org/10.3989/graellsia.2015.v71.135.

Copyright: (c) 2015 SAM y CSIC. Salvo indicación contraria, todos los contenidos de la edición electrónica de Graellsia se distribuyen bajo licencia de uso y distribución Creative Commons Reconocimiento no Comercial 3.0. España (cc-by-nc).

\section{Introduction}

The genus Barbus sensu lato includes more than 800 species and it is one of the genera with the highest number of species among vertebrates. It is a polyphyletic assemblage with different genetic and morphologic features. In fact, in recent years, Barbus phylogenetic studies have led to its division into different genera (Karaman, 1971; Machordom \& Doadrio, 2001a; Yang et al., 2015). 
European and North African species previously included in the genus Barbus Cuvier \& Cloquet, 1843 are presently included in the genera Barbus and Luciobarbus Heckel, 1843 (Kottelat \& Freyhof, 2007). The genus Luciobarbus was initially assigned to the Asian species Luciobarbus esocinus Heckel, 1843 but was long considered as a synonym of Barbus Cuvier \& Cloquet, 1843. Notwithstanding, a phylogenetic study using morphological characters revealed that most limnophilic circum-Mediterranean species occurring in northern Africa, the Mediterranean peninsulas, and the Near East were monophyletic (Doadrio, 1990). This monophyletic clade was included within the subgenus Luciobarbus (Doadrio, 1990), which with the advent of molecular studies, was better defined and recognized at the generic level (Machordom \& Doadrio, 2001b; Tsigenopoulos et al., 2003; Griffiths et al., 2004; Kottelat \& Freyhof, 2007; Yang et al., 2015).

Molecular studies of the genus Luciobarbus have, so far, been based on isoenzyme analysis (Machordom et al., 1995, 1998; Doadrio et al., 1998) and sequencing of mitochondrial genes (Zardoya \& Doadrio, 1999; Zardoya et al., 1999; Machordom \& Doadrio 2001b; Doadrio et al., 2002; Tsigenopoulos et al., 2003). The sequencing of nuclear genes has been constrained by the tetraploid condition of the species of this genus (Yang et al., 2015).

Results of previous molecular studies have revealed a strong Luciobarbus population structure in North Africa (Berrebi et al., 1995; Doadrio et al., 1998; Machordom et al., 1998; Machordom \& Doadrio, 2001b). Sixteen populations, genetically isolated during the late Miocene and Pliocene, were recognized in North Africa, some of them assigned to different species (Machordom \& Doadrio, 2001b). Within North African populations, those of northwestern Morocco, inhabiting areas ranging from the basins of the Laou River (on the Mediterraenan slope in the North) to the Kasab River (on the Atlantic slope in the southwest), have been clustered together by genetic studies (Machordom \& Doadrio, 2001b; Geiger et al., 2014). However, there are few taxonomic studies focusing on Luciobarbus populations of northwestern Morocco, due to its traditional isolation and limited accessibility (Almaça, 1966, 1968, 1970; Doadrio, 1990). For these reasons northern Morocco was ignored, when taxonomic African ichthyological studies were conducted by the French Geographical Society, in the early twentieth century.

Some Luciobarbus populations, mainly from Laou, Grou and Sebou Basins, belonging to northwestern Morocco present high genetic differentiation in several molecular markers, such as isozymes and the mitochondrial cytochrome $b$ gene, compared to other populations of the genus and constitute a monophyletic group (Machordom et al., 1998; Machordom \& Doadrio, 2001b; Geiger et al., 2014). Nonetheless, only morphological works have been carried out for the Sebou Basin (Almaça, 1966, 1968, 1970; Doadrio, 1990). The aim of our study was to extend the molecular and morphological works to other populations from northwestern Morocco. Thus, our goal was to clarify, with a more complete sampling, the taxonomy of Luciobarbus in northwestern Morocco with an integrative approach and unravel whether the diversity found corresponds to new taxa that may not have been formally described so far. In this case, we will formally describe these new taxa.

\section{Material and Methods}

\section{MORPHOLOGICAL ANALYSES}

The taxonomy of the population of northwestern Morocco was based on 47 specimens from Laou Basin, 43 specimens from Loukos Basin, 22 specimens from Hachef Basin, 55 specimens from Sebou Basin, 33 specimens from Bou Regreg Basin and 23 specimens from Kasab Basin (Fig. 1, Table 1).

The material studied comsisted of the following locations and number of specimens: 25 adult specimens from the Laou River, Laou Basin, Derdara, (35.118986, -5.288900), Morocco (Voucher numbers: MNCN 290.639-290.652, 290.655, 290.657-663, 290.665-667); 22 specimens from the Laou River, Laou Basin, Beni Ferten (35.353254, -5.184840), Morocco (Voucher numbers: MNCN 284.939-940, 284.942945, 284.947-284.948, 284.950-951，284.953-964); 43 specimens from the Loukos River, Loukos Basin, Souk Had, Laghdir (35.02624,-5.404660), Morocco (Voucher numbers: MNCN: 280.162-163, $280.165,280.168,280.170,280.172-174,280.176-$ 181, 280.183, 280.185-186, 290.671-696); 22 specimens from the Hachef River, Hachef Basin, Dar Chaoui (35.526763,-5.713771), Morocco (MNCN 290.707$714 ; 290.716-722 ; 290.725-731) ; 32$ specimens from the Ifrane River, Sebou Basin, Ouad Ifrane, (33.296957, -5.492639) Morocco (voucher numbers: MNCN 279.711-729, 290.731, 279.733-744); 23 specimens from the Tizguit River, Sebou Basin, Ifrane (33.549241, -5.097144), Morocco (Voucher number: MNCN 71675-697); and 33 specimens from the Grou River, Bou Regreg Basin, Sebt Ait Rahhou (33.164678, -6.366963), Morocco (Voucher numbers: MNCN 71725-746, 71918-28). For comparative purposes, we analyzed 23 specimens of Luciobarbus ksibi Boulenger 1905 from species type locality in the Kasab River, Kasab Basin, Essaouira (31.465857,-9.759850) Morocco (Voucher numbers: MNCN 105.460-65, $105.469,234.925-29,280.483-485,71220-21,71223-$ 26, 71230, 290.670). All sampling sites (Fig. 1) presented similar riverine morphology, with clear water and fast current and gravel bottom, with the exception of the Kasab River, in Essaouira, which showed a more marked seasonal regime and poorer water conditions. 


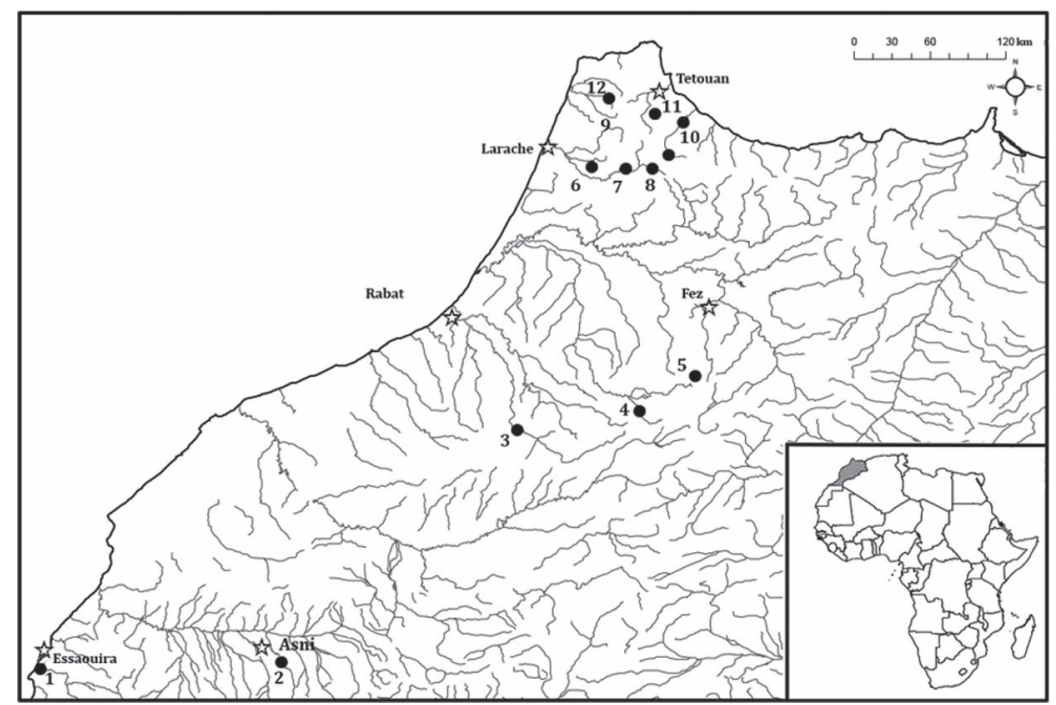

Fig. 1.- Geographic distribution of Luciobarbus spp. and sampling localities. The numbers on map correspond to localities in Table 1.

Fig. 1.-Distribución geográfica de Luciobarbus spp. y localidades muestreadas. La correspondencia entre números y localidades se puede ver en la Tabla 1.

Table 1.-Sampling localities for Luciobarbus spp. Code is the number on the phylogenetic tree. $\mathrm{G}=$ Genetic, $\mathrm{M}=$ Morphometry.

Tabla 1.- Localidades muestreadas de las especies de Luciobarbus estudiadas. El código es el número que aparece en el árbol filogenético. $\mathrm{G}=$ análisis genético. $\mathrm{M}=$ análisis morfométrico.

\begin{tabular}{|c|c|c|c|c|c|c|c|}
\hline Species & River & Locality & Basin & Analyses & Code & GenBank & Map \\
\hline L. ksibi & Kasab & Essaouira & Kasab & G,M & K6-K10 & KT003951-55 & 1 \\
\hline L. ksibi & Reraia & Asni & Tensift & $\mathrm{G}$ & K1-K5 & KT003956-60 & 2 \\
\hline L. sp1 & Tizguit & Ifrane & Sebou & $M$ & & & 4 \\
\hline L. sp1 & Ifrane & Ouad Ifrane & Sebou & $\mathrm{G}, \mathrm{M}$ & S1-S6 & KT003941-45 & 5 \\
\hline L. $s p 2$ & Tattofte & Ouled Soltane & Loukos & M & & & 6 \\
\hline L. sp2 & Loukos & Mouries & Loukos & M & & & 7 \\
\hline L. sp2 & Loukos & Souk Had, Laghdir & Loukos & $\mathrm{G}$ & RK1-RK5 & КТ003936-40 & 8 \\
\hline L. sp2 & Hachef & Dar Chaoui & Hachef & $\mathrm{G}, \mathrm{M}$ & $\mathrm{RH} 1-\mathrm{RH} 5$ & KT003931-35 & 9 \\
\hline L. $s p 2$ & Laou & Derdara & Laou & G,M & RL1-RL5 & КТ003926-30 & 10 \\
\hline L. sp2 & Laou & Beni Ferten & Laou & M & & & 11 \\
\hline L. sp3 & Bou Regreg & Sebt Ait Rahhou & Grou & $\mathrm{G}$ & B1-B5 & KT003946-50 & 3 \\
\hline L. capito & Terek & Kizlyar & Terek (Russia) & $\mathrm{G}$ & L. capito & AF045975 & \\
\hline
\end{tabular}

Twenty-three morphometric measurements (in mm) and nine meristic variables were recorded from digital photographs using TpsDig v.1.4 (Rohlf, 2003). The following abbreviations were used for morphometric and meristic characters: A, anal fin rays; $\mathrm{AFH}$, anal fin height; AFL, anal fin length; APL, anal peduncle length; BL1, first barbel length; BL2, second barbel length; BD, body depth; LBD, lowest body depth; C, central caudal fin rays; CFL, caudal fin length; CPL, caudal peduncle length; D, dorsal fin rays, DFL dorsal fin length; DFH dorsal fin height; ED, eye diameter;
HL, head length; LL lateral line scales; P, pectoral fin rays; PFL, pectoral fin length; PrAD, pre-anal distance; PrDD, pre-dorsal distance; PrOL, pre-orbital length; PrPD, pre-pectoral distance; PrVD, pre-ventral distance; PsOL, postorbital length; PVL, pectoral-ventral length; RSA, scale rows above lateral line; RSB scale rows below lateral line; SL, standard length; V, ventral fin rays; VFL, ventral fin length; VE, Number of vertebrae. The number of vertebrae was obtained by direct counting on X-ray images of individuals from all populations sampled. 
After constructing the measurement matrix, Burnaby's method was used to correct size effect (Burnaby, 1966; Rohlf \& Bookstein, 1987). All analyses were conducted with the corrected matrix. Morphometric and meristic characters were analyzed independently. A two-way analysis of variance (ANOVA) comparing morphometric characters was conducted to test for sexual dimorphism and variation among populations. To identify the variables that contributed most to the variation between populations, a principal components analysis (PCA) was performed using the covariance matrix for morphometric characters.

\section{MOLECULAR ANALYSES}

For the molecular approach, we analyzed samples corresponding to individuals of Luciobarbus spp. from Sebou, Laou, Hachef, Loukos and Bou Regreg basins; and Luciobarbus ksibi from the Kasab Basin (Table 1). The species Luciobarbus capito (Güldenstädt, 1773) was selected as outgroup based on previous phylogenetic analyses (Zardoya \& Doadrio, 1999). Total genomic DNA was extracted from fin-clip tissue using the commercial kit Biosprint 15 for tissue and blood (Qiagen). For each specimen, the complete region (1140bp) of the mitochondrial cytochrome $b$ (cyt $b$ ) was amplified. Primers and protocols used for PCR for cytb followed Machordom \& Doadrio (2001b). After checking PCR products on 1\% agarose gels, they were purified by ExoSAP-ITTM (USB) and directly sequenced on MACROGEN service using a 3730XL DNA sequencer. All sequences were deposited in the GenBank database (Accession Numbers: KT003926-KT003960).

\section{PHYLOGENETIC ANALYSES}

Phylogenetic analyses were performed using Bayesian inference (BI) implemented in MrBayes v.3.2 (Ronquist et al., 2012). The Akaike Information Criterion (Akaike, 1973) implemented in jModeltest (Posada, 2008) was used to determine the evolutionary model that best fit the data. In this case $\mathrm{TrN}+\mathrm{I}$ model was selected $(\mathrm{R}(\mathrm{a})[\mathrm{AC}]=1.0000, \mathrm{R}(\mathrm{b})[\mathrm{AG}]=92.1342$, $\mathrm{R}(\mathrm{c})[\mathrm{AT}]=1.0000, \mathrm{R}(\mathrm{d}) \quad[\mathrm{CG}]=1.0000, \mathrm{R}(\mathrm{e})$ $[C T]=20.3361, R(f)[G T]=1.0000, p$-inv $=0.7900)$. BI was performed using two independent runs of four Markov Montecarlo coupled chains (MCMC) of $10^{6}$ generations each, to estimate the posterior probability distribution. Topologies were sampled every 100 generations, and majority-rule consensus tree was estimated after discarding the first $10 \%$ of generations. Robustness of clades was assessed using Bayesian posterior probabilities. The average genetic distances among Luciobarbus populations were calculated for each gene using MEGA package v.6.0 (Tamura et al., 2013) according to the uncorrected- $p$ distances.

\section{Results and Discussion}

\section{COMPARISON OF MORPHOLOGY AMONG POPULATIONS}

Two-way analysis of variance (ANOVA), testing for sexual dimorphism and differentiation among populations, showed significant differences $(p<0.05)$ for the variables standard length, postorbital length, and anal fin size (Table 2). In absolute values all variables were greater in females, but proportionally to the standard length postorbital length was longer in males (Table 3 ). A non-biological interpretation could explain the differences in postorbital length by sex, therefore we performed a test of Mann-Whitney-Wilcoxon at $p<0.05$, with postorbital length and sex as variables, for each population independently. The null hypothesis for identical postorbital length between males and females for each population was not rejected in all populations (Sebou Basin $z=-0.810$; Bou Regreg Basin $z=-0.868$; Kasab Basin $z=-1.692$; Loukos Basin $z=-0.480$; Laou Basin $z=-0.343$; Hachef Basin $z=-0.032$ ). Therefore, the differences in postorbital length were not explained by sex and were an effect of population differences.

Females had proportionally higher and longer anal fins (Table 3). Sex differences in the size of anal fins have been found in other Luciobarbus species, and are probably associated with the female's use of the anal fin to excavate nests in the riverbed (Banarescu \& Bogutskaya, 2003). Nuptial tubercles were present in the snout and head of males, particularly around the preorbital region.

To deal with the presence of sexual dimorphism in anal fin size, we removed AFL and AFH from posterior analyses. Most morphometric variables showed significant differences between populations in the two-way ANOVA analysis (Table 2). An analysis of body proportions based on Kruskal-Wallis and MannWhitney post hoc comparisons, was used to detect differences in body shape that can masked if only linear untransformed measurements are taken into account (Appendix 1). We grouped the populations from the Rif Mountains (Laou, Loukos, and Hachef Basins) based on mitochondrial DNA analysis and previous genetic studies (Machordom et al., 1998, Machordom \& Doadrio, 2001b; Geiger et al., 2014). The populations from Sebou Basin showed a shorter predorsal distance and a longer caudal peduncle than the other Luciobarbus populations studied, due to the more anterior position of the dorsal fin (Fig. 2, Table 4).

The Sebou population exhibited greater postorbital length with respect to the other studied populations, and therefore the ratio SL/PsOL in the Sebou population was the lowest (Table 4). The caudal peduncle was higher in Luciobarbus ksibi (Kasab population) than in the other studied populations, and the ratios CPL/CPI and APL/BLD, were the lowest-. Barbels were longest in Luciobarbus ksibi. Preorbital length 
Table 2.- Two-way analysis of variance (ANOVA) for sexual dimorphism, population variation, and their interaction. Significant differences $p<0.05\left(^{*}\right) ; p<0.01\left(^{* *}\right) . N=163$ males and $n=60$ females. Acronyms are defined in the Material and Methods.

Tabla 2.- Análisis de la varianza (ANOVA) de dos vías para dimorfismo sexual, variación poblacional y su interacción. Diferencias significativas $p<0,05\left(^{*}\right) ; p<0,01$ $\left({ }^{*}\right) . \mathrm{N}=163$ machos and $\mathrm{N}=60$ hembras. Las abreviaturas se describen en el epígrafe de Material y Métodos.

\begin{tabular}{|c|c|c|c|}
\hline Variables & $\begin{array}{c}\text { Sexual dimorphism } \\
(f / p \text {-value })\end{array}$ & $\begin{array}{c}\text { Population Variation } \\
\text { (f/p-value) }\end{array}$ & $\begin{array}{c}\text { Sex/pop variation } \\
(\mathrm{f} / \mathrm{p} \text {-value })\end{array}$ \\
\hline SL & $4.51 /^{*}$ & $53.38 / * \star$ & $2.37 /$ \\
\hline $\mathrm{HL}$ & $3.06 /$ & 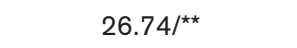 & $1.94 /$ \\
\hline PrOL & $1.45 /$ & $13.36 / \star \star$ & $2.08 /$ \\
\hline ED & $0.22 /$ & $11.32 / * \star$ & $0.57 /$ \\
\hline $\mathrm{PsOL}$ & $22.32 / * \star$ & $469.5 /^{\star \star}$ & $7.58 / * \star$ \\
\hline B1L & $3.45 /$ & $10.09 /^{\star \star}$ & $2.17 /$ \\
\hline B2L & $1 /$ & $21.07 / * \star$ & $0.19 /$ \\
\hline PrDD & $1.66 /$ & $78.49 / * \star$ & $2.14 /$ \\
\hline PrPD & $0.01 /$ & $44.54 /^{\star \star}$ & $4 / * \star$ \\
\hline PrVD & $3.18 /$ & $68.28 /^{\star *}$ & $3.55 /^{*}$ \\
\hline PrAD & $1.75 /$ & $56.71 /$ ** & $3.5 /^{*}$ \\
\hline $\mathrm{CPL}$ & $0.96 /$ & $11.14 / * \star$ & $1.92 /$ \\
\hline APL & $0.51 /$ & $3.68 /^{\star}$ & $4.39 / * \star$ \\
\hline PVL & $0.01 /$ & $12.711^{\star \star}$ & $0.51 /$ \\
\hline BD & $3.13 /$ & $9.64 /^{\star \star *}$ & $1.34 /$ \\
\hline BLD & $0.001 /$ & $6.93 /^{\star \star *}$ & $1.61 /$ \\
\hline DFL & $2.04 /$ & $2.9 /$ & $0.137 /$ \\
\hline DFH & $3.31 /$ & $27.42 /{ }^{\star \star}$ & $2.32 /$ \\
\hline PFL & $0.10 /$ & $23.08 /^{\star}$ & $1.8 /$ \\
\hline VFL & $2.42 /$ & $14.26 / * \star$ & $0.19 /$ \\
\hline AFL & $4.26 /^{*}$ & $16.61 /$ & $2.37 /$ \\
\hline AFH & $11.46 / * \star$ & $29.88 / * \star$ & $2.06 /$ \\
\hline CFL & $0.87 /$ & $16.08 / * \star$ & $1.41 /$ \\
\hline
\end{tabular}

was significantly shorter in the Bou Regreg population compared to the other populations studied.

Lateral line scales were more numerous in the Bou Regreg population than in other populations. Scales

Table 3.- Morphometric variables showing significant sexual dimorphism ( $p$ 0.05). Values are mean (minimum-maximum). Acronyms are defined in the Material and Methods.

Tabla 3.- Variables morfométricas que muestran dimorfismo sexual significativo $(p<0.05)$. Los valores son medias y entre paréntesis valores máximos y mínimos. Las abreviaturas están descritas en el epígrafe de Material y Métodos.

\begin{tabular}{lcc}
\hline Variables $(\mathbf{m m})$ & Males $\mathbf{n = 1 6 3}$ & Females $\mathbf{n}=\mathbf{6 0}$ \\
\hline $\mathrm{SL}$ & $106.2(53.1-232.8-75)$ & $157.7(82.1-240.1)$ \\
$\mathrm{PsOL}$ & $13.5(6.6-30.8)$ & $18.9(9.6-29.6)$ \\
$\mathrm{AFL}$ & $8.3(3.74-17.8)$ & $12.3(6.2-19.3)$ \\
$\mathrm{AFH}$ & $18.3(10-41.6)$ & $27.5(15-44.8)$ \\
\hline
\end{tabular}

numbers on the superior transverse line were higher in Bou Regreg and Rifian populations than in L. ksibi and Sebou populations, while the number of scales on the inferior transverse line was lower in Rifian populations and L. ksibi (Table 4).

The principal component analysis divided the populations into three groups corresponding to Luciobarbus $k s i b i$ and populations of the Rifian and the Sebou Basins. The population of the Bou Regreg Basin was included in the morphometric variability of Rifian populations (Fig. 3). Nevertheless, the Bou Regreg population could be discriminated from the other studied populations by the number of scales on the body (Fig. 4).

The eigenvalues of the two first principal components, with the Burnaby-corrected matrix, explained most of the variance (Table 5). The highest values for eigenvectors in both males and females, and, consequently, the variables that contributed most to the ordination in the PCA were: postorbital and preorbital length, caudal and dorsal fin size, and barbel length (Table 5). 


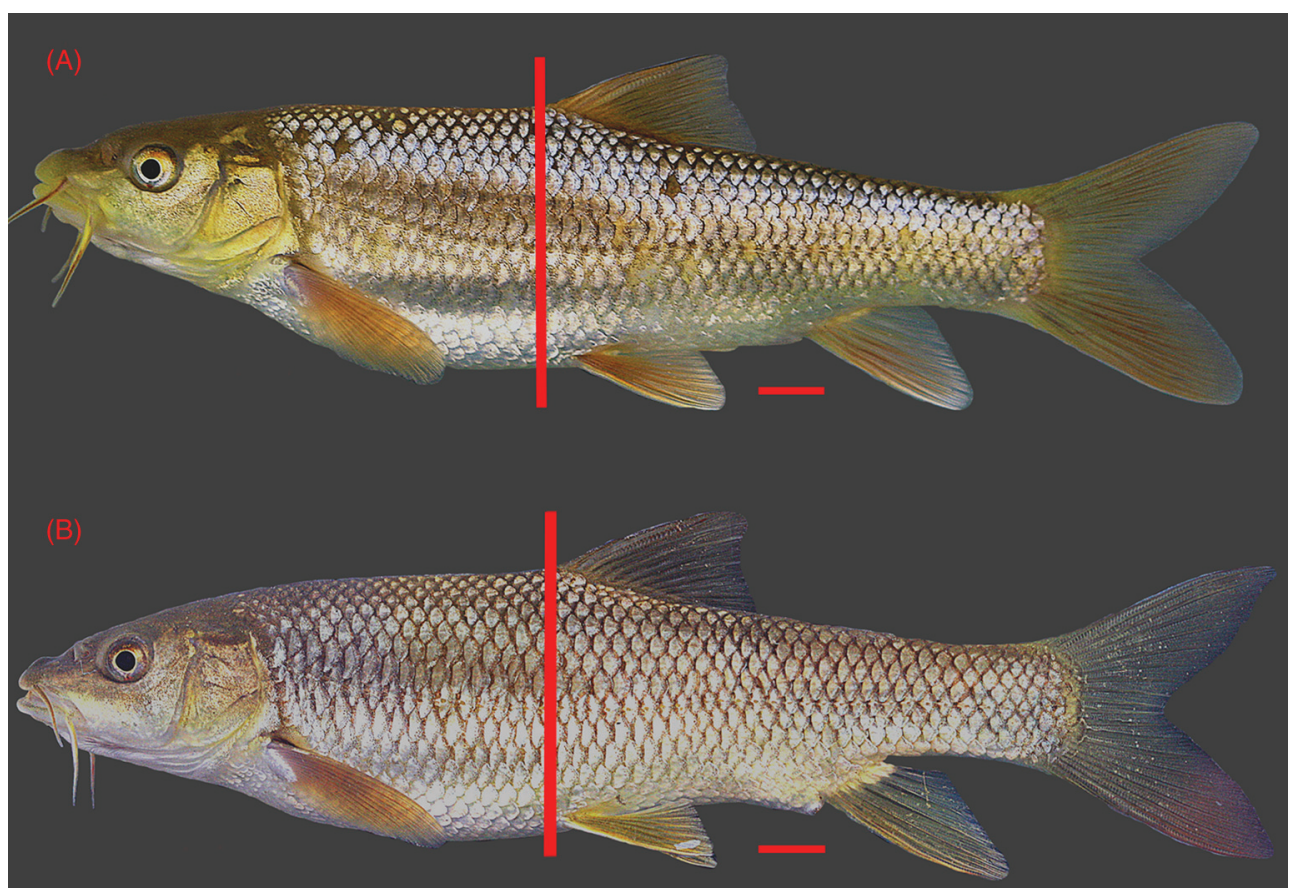

Fig. 2.- Comparison of two females of similar standard length from (A) Sebou Basin and (B) Laou Basin (Rifian population) showing differing position of the dorsal fin with respect to ventral fin insertion.

Fig. 2.- Comparación entre dos hembras de similar longitud estándar de las cuencas del Sebou (A) y del río Laou (población del Rif) (B) mostrando la diferente posición de la aleta dorsal con respecto al origen de la aleta ventral.

Table 4.- Ratios of morphometric variables and scale count. Values are mean (minimum and maximum). Acronyms are defined in the Material and Methods.

Tabla 4.- Valores de la media, y entre paréntesis valores mínimos y máximos, para diferentes proporciones de las variables morfométricas y número escamas. Las abreviaturas están descritas en el epígrafe de Material y Métodos.

\begin{tabular}{lcccc}
\hline Measurements & $\begin{array}{c}\text { Rif populations } \\
(\mathbf{n = 1 1 2})\end{array}$ & $\begin{array}{c}\text { Sebou } \\
(\mathbf{n = 5 5})\end{array}$ & $\begin{array}{c}\text { Bou Regreg } \\
(\mathbf{n}=\mathbf{3 3})\end{array}$ & $\begin{array}{c}\text { Luciobarbus } \\
\boldsymbol{k s i b i}(\mathbf{n = 2 3})\end{array}$ \\
\hline $\mathrm{SL} / \mathrm{PrDD}$ & $1.87(1.79-1.95)$ & $1.93(1.79-2.03)$ & $1.85(1.78-1.96)$ & $1.85(1.73-1.98)$ \\
$\mathrm{SL} / \mathrm{CPL}$ & $2.81(2.56-3.06)$ & $2.7(2.54-2.91)$ & $2.79(2.63-2.91)$ & $2.82(2.63-3.17)$ \\
$\mathrm{HL} / \mathrm{PsOL}$ & $2.21(1.65-2.50)$ & $1.61(1.29-1.81)$ & $2.04(2.47-3.41)$ & $2.23(2.03-2.57)$ \\
$\mathrm{HL} / \mathrm{PrOL}$ & $2.74(2.35-3.23)$ & $2.82(2.48-3.49)$ & $2.97(2.47-3.5)$ & $2.78(2.4-3.1)$ \\
$\mathrm{SL} / \mathrm{BLD}$ & $9.11(7.48-10.92)$ & $8.72(7.57-10)$ & $8.38(8.06-8.7)$ & $7.8(7.36-8.27)$ \\
$\mathrm{CPL/BLD}$ & $3.24(2.46-3.83)$ & $3.24(2.67-3.75)$ & $3(2.81-3.26)$ & $2.78(2.6-2.99)$ \\
$\mathrm{APL/BLD}$ & $1.64(1.25-2.07)$ & $1.58(1.37-1.83)$ & $1.55(1.39-1.67)$ & $1.5(1.29-1.87)$ \\
$\mathrm{HL} / \mathrm{L} 1 \mathrm{~B}$ & $4.16(2.78-6.87)$ & $3.96(3.03-5.27)$ & $4.11(3.8-4.5)$ & $3.5(2.93-4.05)$ \\
$\mathrm{HL} / \mathrm{L} 2 \mathrm{~B}$ & $3.27(2.48-5)$ & $3.1(2.4-4.74)$ & $3.29(3.05-3.52)$ & $2.65(2.26-3.25)$ \\
$\mathrm{LL}$ & $43.9(46-42)$ & $43.7(41-47)$ & $46.5(45-50)$ & $43.7(41-47)$ \\
$\mathrm{RSA}$ & $8.8(8.5-9.5)$ & $7.5(7.5-8.5)$ & $9.6(8.5-10.5)$ & $8.3(6.5-8.5)$ \\
$\mathrm{RSB}$ & $4.7(3.5-5.5)$ & $5.5(4.5-6.5)$ & $6.74(6.5-7.5)$ & $4.98(4.5-5.5)$ \\
\hline
\end{tabular}

\section{OSTEOLOGICAL FEATURES}

The hardness of the last single ray of the dorsal fin (DFR) and its number of denticulations frequently has been used in the taxonomy of Luciobarbus
(Almaça, 1970). As Doadrio (1990) pointed out, there is ontogenetic variability in DFR, and comparison of the characteristics of DFR among species, for taxonomic purposes, must be done using adult specimens (Appendix 2-1). We found L. ksibi presents strong 


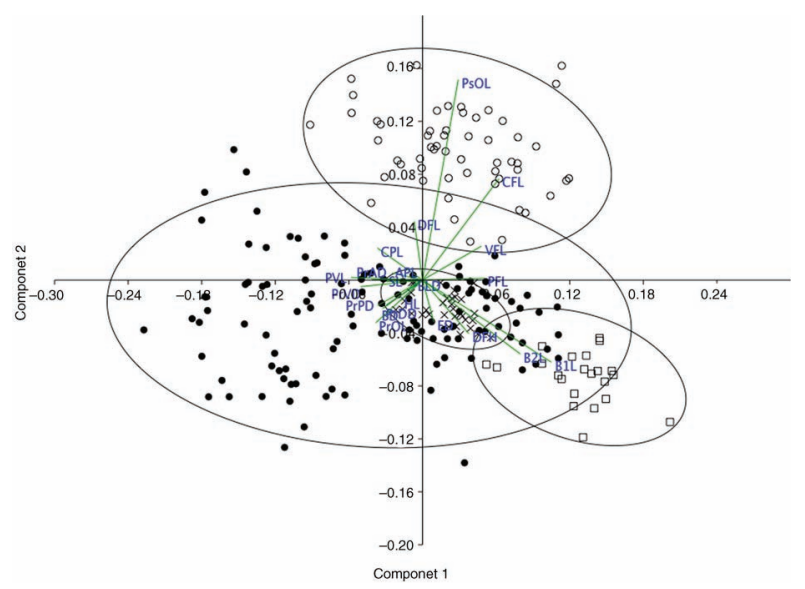

Fig. 3.- Variables that most contributed to the PCA analysis. Dots, Rifian populations. Squares, Luciobarbus ksibi from Kasab Basin. X, Population from Bou Regreg Basin. Circles, population from Sebou Basin. Abbreviations are defined in Materials and Methods.

Fig. 3.- Variables que más contribuyen al ordenamiento en el PCA. Puntos poblaciones del Rif. Cuadrados Luciobarbus ksibi de la cuenca del Kasab. Equis población de la cuenca del Bou Regreg. Círculos población de la cuenca del Sebou. Las abreviaturas están descritas en el epígrafe de Material y Métodos.

denticulations but only over $2 / 3$ of the DFR length. Denticulations of the DFR in specimens of the Bou Regreg population were deep and the length of these denticulations was greater than the width of the ray. Dorsal fin rays of the Rifian and Sebou basins populations were similar, slightly stronger in Rifian populations than in the Sebou population.

The skulls of $L$. ksibi and Sebou populations are shorter and wider than those of the Bou Regreg and Rifian populations. The ethmoid bone in the Sebou population is narrower than in other studied populations, especially pronounced compared to the Rifian population (Append. 2-2). In the skull lateral view, the opercular bone appeared longer in the Sebou population than in other populations (Append. 2-3). Infraorbital bones are larger in $L$. ksibi than in other populations, and the second infraorbital bone is longer in Rifian than in other populations and usually exhibits four pores (Append. 2-4). The pharyngeal bone is thinner in the Bou Regreg populations and wider in L. ksibi. The dorsal branch of the pharyngeal bone forms a closed angle with respect to inferior branch in Rifian population and L. ksibi (Append. 2-5).

\section{MOLECULAR DATA}

Phylogenetic analyses based on the cytb gene supported four main clades in the tree, corresponding to the populations of the Rif, Sebou, and Bou Regreg Basins and Luciobarbus ksibi (Fig. 5). The genetic distances found among populations are presented in Table 6. Genetic distances within Sebou, Bou Regreg, and Rifian populations and $L$. ksibi ranged between $0-0.6 \%$ but between these populations were $1.7-3.9 \%$. The minimum value was found between $L$. ksibi and Bou Regreg populations (Table 6).

The distances are of similar range as those between well recognized species of cyprinid fishes (Doadrio et al., 2002, 2007a, 2007b; Doadrio \& Carmona, 2003, 2006; Doadrio \& Madeira, 2004; Robalo et al., 2005; Doadrio \& Elvira, 2007; DomínguezDomínguez et al., 2007, 2009). These results confirm the differences found with allozyme analyses (Machordom et al., 1998). Allozyme studies found 23 polymorphic loci, four of which (MPI, GPI-5, IDHP-2, CK) were diagnostic, with a probability criterion of $99 \%$ of correct assignment to Rifian populations with respect to the Sebou Basin. Between the Sebou Basin (Ifrane population) and Grou Basin three diagnostic loci were found (GPI-2*, GPI-5* and PGDH-1). The population of the Grou River (Bou Regreg Basin) exhibited a unique diagnostic locus $(G P I-2 * 118)$ with respect to all Luciobarbus populations (Machordom et al., 1998). Populations from Sebou, Rif and Bou Regreg basins were identified as different taxa by other authors based on the molecular differences found, but were not formally described as new so far (Machordom et al., 1998).

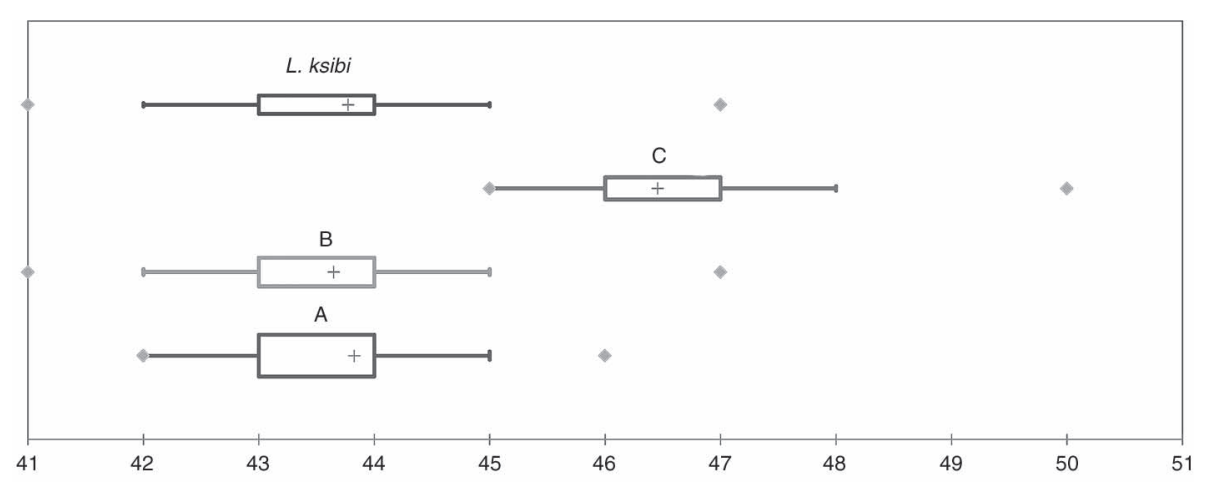

Fig. 4.- Box-plots of lateral line scale numbers. A, Rifian population; B, Sebou Basin population; C, Bou-Regreg Basin population. Fig. 4.- Box-plots para el número de escamas en la línea lateral. A, Población del Rif; B, Población de la Cuenca del Sebou; C, Población de la Cuenca del Bou Regreg. 
Table 5.- Eigenvalues and eigenvectors for the first three principal components (PC1-PC3) of 21 morphometric variables for all Luciobarbus populations. Acronyms are defined in the Material and Methods. In bold, variables with the highest eigenvectors for each PC.

Tabla 5.- Eigenvalores y eigenvectores para los tres primeros componentes principales (PC1-PC3) de 21 variables morfométricas para todas las poblaciones del género Luciobarbus. Las abreviaturas están descritas en el epígrafe de Material y Métodos. En negrita, variables con los eigenvectores más altos para cada CP.

\begin{tabular}{lccc}
\hline Variables & PCI & PCII & PCIII \\
\hline Eigenvalue & 0.0073 & 0.0044 & 0.0029 \\
\% variance & 29.1 & 17.56 & 11.48 \\
\multicolumn{4}{c}{ Eigenvectors } \\
SL & -0.1416 & -0.0053 & 0.0137 \\
PrDD & -0.1419 & -0.0904 & 0.0254 \\
PrPD & -0.1741 & -0.0915 & -0.0420 \\
PrVD & -0.2401 & -0.0236 & -0.0667 \\
PrAD & -0.1961 & 0.0014 & -0.0377 \\
PVL & -0.2772 & 0.0095 & -0.0804 \\
CPL & -0.1750 & 0.1154 & 0.0243 \\
APL & -0.1185 & 0.0260 & 0.1110 \\
BD & -0.1550 & -0.1024 & -0.0021 \\
BLD & -0.0296 & -0.0078 & -0.0763 \\
HL & -0.0841 & -0.0731 & -0.0450 \\
PrOL & -0.1817 & -0.1536 & -0.0761 \\
ED & 0.0442 & -0.1513 & -0.1591 \\
PsOL & 0.1385 & $\mathbf{0 . 7 2 0 5}$ & -0.3674 \\
B1L & $\mathbf{0 . 5 0 0 1}$ & -0.2952 & -0.4918 \\
B2L & $\mathbf{0 . 3 7 9 4}$ & -0.2658 & -0.1933 \\
PFL & 0.2412 & 0.0068 & 0.2772 \\
VFL & 0.2282 & 0.1219 & 0.1780 \\
DFL & -0.0322 & -0.2115 & -0.0283 \\
DFH & 0.1795 & 0.3645 & $\mathbf{0 . 4 9 5 8}$ \\
CFL & 0.2966 & $\mathbf{0 . 2 5 8 6}$ & $-\mathbf{0 . 4 0 4 6}$ \\
\hline & & & \\
\hline & & & \\
\hline
\end{tabular}

\section{TAXONOMY OF LUCIOBARBUS LABIOSUS (PELLEGRIN, 1920)}

Initially the population from Sebou Basin in Morocco was considered to belong to Barbus setivimensis Valenciennes, 1842, which was originally described for populations of the Setif Basin in Algeria (Pellegrin, 1920). Within the Sebou population of B. setivimensis, Pellegrin (1920) found specimens with welldeveloped lips that this author described as a variety, B. setivimensis var. labiosa Pellegrin, 1920. This development of the lips in some specimens of the former genus Barbus sensu lato, currently within Luciobarbus, is common, and Pellegrin (1922) described another variety as Barbus massaensis var. labiosa Pellegrin, 1922. As Almaça (1968, 1970) stated, Pellegrin (1920) did not describe the var. labiosa as a subspecific category or geographic form because he found typical specimens of $B$. setivimensis and some specimens with more developed lips in the same locality. For this reason Article 45.6.4 of the International Code of Zoological Nomenclature is not applicable:

"45.6.4. it is subspecific if first published before 1961 and its author expressly used one of the terms "variety" or "form" (including use of the terms "var.", "forma", "v." and "f."), unless its author also expressly gave it infrasubspecific rank, or the content of the work unambiguously reveals that the name was proposed for an infrasubspecific entity, in which case it is infrasubspecific"

Subsequent molecular studies showed that populations of L. setivimensis of the Setif Basin in Algeria and those of the Sebou Basin in Morocco were not monophyletic. Thus, mitochondrial genes of species of Luciobarbus showed that L. setivimensis from the Setif Basin is a sister group of the Iberian species, while populations of $L$. setivimensis from the Sebou Basin were closer to North African species (Machordom \& Doadrio, 2001b). For this reason, and in the absence of another valid name for the populations of the Sebou Basin, molecular studies have referred to Sebou populations as Luciobarbus labiosa (Machordom \& Doadrio, 1993, 2001b; Doadrio, 1994; Geiger et al., 2014).

Hence, populations from the Sebou Basin do not have a valid specific name at the present time, and we describe here this population as a new species.

\section{DESCRIPTION OF LUCIOBARBUS POPULATIONS}

The high degree of morphological and genetic differentiation of Luciobarbus populations endemic to the region of the Strait of Gibraltar in North Africa justifies the consideration of these populations as distinct species. No available name for these populations exists, and therefore three new species are described in this study.

Luciobarbus maghrebensis Doadrio, Perea \& Yahyaoui, sp. nov.

urn:1sid:zoobank.org:act:3FE3F718-F0 50-44F5-93DCC5ABFE3C8674

TYPe MATERIAL: Holotype: Fig. 6, Table 7. MNCN 279.718 female, 135.6 mm (SL); Ifrane River, Sebou Basin, Ouad Ifrane, Atlantic slope in Morocco (33.296957, -5.492639) (Fig. 1); 27/3/2013. Collected by (Coll.) Doadrio, I.; Garzón, P.; Yahyaoui, A; González, E. G.; Perea, S.

Paratypes: Table 7. MNCN 279.711-717, 279.719-29, 279.731, 279.733-744: Thirty-one specimens from the Ifrane River, Sebou Basin, Ouad Ifrane, Atlantic slope in Morocco (33.296957,-5.492639); 27/3/2013. Coll. Doadrio, I; Yahyaoui, A.; Garzón, P.; González, E. G.; Perea, S. MNCN 71675-697: Twenty-three specimens from Tizguit River, Sebou Basin, Ifrane, Atlantic slope in Morocco (33.549241,-5.097144). 19/4/1991. Doadrio, I; Garzón, P. 


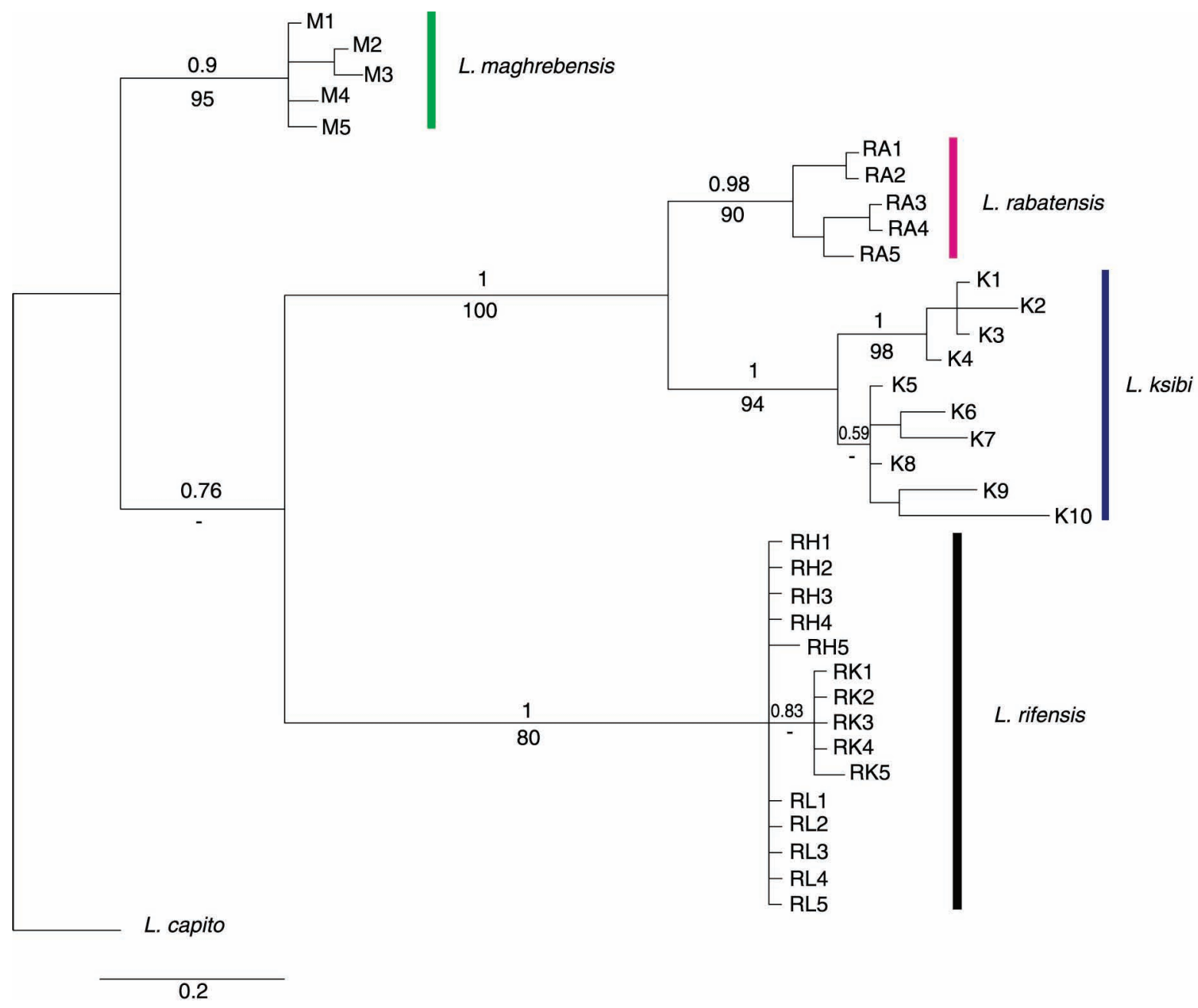

Fig. 5.- Phylogenetic tree rendered by Bayesian Inference of the cytochrome $b$ gene. Numbers on branches indicate posterior probability values. Abbreviations of localities are defined in Table 1.

Fig. 5.- Árbol filogenético obtenido por Inferencia Bayesiana para el gen citocromo b. Los números en las ramas indican los valores de probabilidad posterior. Las abreviaturas de las localidades se muestran en la Tabla 1.

Holotype and a series of paratypes ( 55 specimens) have been deposited at the Fish Collection of the Museo Nacional de Ciencias Naturales, (Madrid, Spain).

Table 6.- Genetic distances for complete mitochondrial cytb gene. Uncorrected genetic distances between populations are presented below diagonal. In the diagonal uncorrected genetic distances within populations are shown.

Tabla 6.- Distancias genéticas. Por debajo de la diagonal distancias genéticas no corregidas entre poblaciones para el gen mitocondrial cytb. En la diagonal distancias genéticas no corregidas dentro de poblaciones.

\begin{tabular}{lccccc}
\hline & $\begin{array}{c}\text { Laou } \\
\text { (Rif) }\end{array}$ & $\begin{array}{c}\text { Hachef } \\
\text { (Rif) }\end{array}$ & $\begin{array}{c}\text { Loukos } \\
\text { (Rif) }\end{array}$ & Sebou & $\begin{array}{c}\text { Bou } \\
\text { Regreg }\end{array}$ \\
\hline Hachef & 0.0 & & & & \\
Loukos & 0.2 & 0.2 & & & \\
Sebou & 3.2 & 3.2 & 3.2 & & \\
Bou Regreg & 3.9 & 3.9 & 3.9 & 3.1 & \\
L. ksibi & 3.8 & 3.8 & 3.9 & 3.7 & 1.7 \\
\hline
\end{tabular}

SupPlementary Material: Lectotype of Barbus setivimensis var. labiosa Pellegrin, 1920: MNHN-IC-1920-0215, Fez, Morocco. Coll. M. CH. Allaud. Paralectotypes of Barbus setivimensis var. labiosa Pellegrin, 1920: MNHN-IC-1920-0212 and MNHN-IC-1920-0214, Fez, Morocco.

DIAGNOSIS: Differs from other known species of Luciobarbus by the following combination of characters: 41-47 scales on the lateral line $(\bar{x}=43.7$ Median $=44)$; 7.5-8.5 $(\bar{x}=7.5$ Median=7.5) above lateral line and 4.5$6.5(\bar{x}=5.47$, Median=5.5) below lateral line. Insertion of the ventral fin is posterior to dorsal fin origin. The last single fin ray is strongly ossified and densely denticulated along its length (Append. 2-1). Postorbital length is longer than that of other studied populations. The PrOL/PsOL ratio ranged from 0.69 to $0.84(\bar{x}=0.77)$. In adult specimens, the lower lip is thick with a retracted medial lobe revealing the dentary. The ethmoid bone is narrower than its length. Vertebrae 41-43 $(\bar{x}=42.1$, $n=12)$, Gill Rakers (GR) 13-15 ( $\bar{x}=14.1$ Median=14). Differences in diagnostic characters among analyzed Luciobarbus populations are presented in Table 10. 


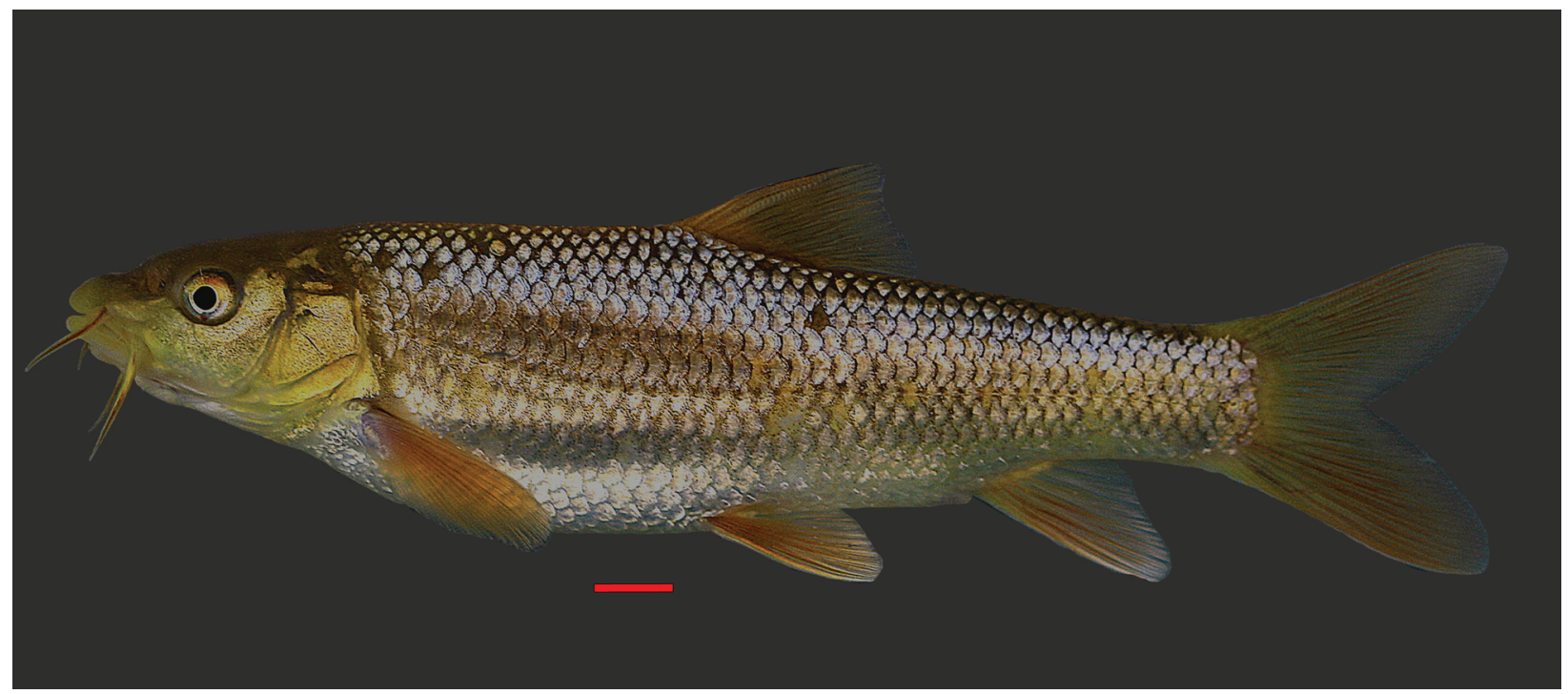

Fig. 6.- Holotype of Luciobarbus maghrebensis from the Ifrane River, Sebou Basin, Ouad Ifrane, Morocco. MNCN 279.718. Fig. 6.- Holotipo de Luciobarbus maghrebensis del río Ifrane, Cuenca del Sebou, en Ouad Ifrane, Marruecos. MNCN 279.718.

Table 7.- Morphometric and meristic measurements of the holotype and paratypes of Luciobarbus maghrebensis.

Tabla 7.-Medidas morfométricas y merísticas del holotipo y paratipos de Luciobarbus maghrebensis.

\begin{tabular}{|c|c|c|c|c|}
\hline \multirow{2}{*}{$\begin{array}{l}\text { Morphometric } \\
\text { variables }\end{array}$} & \multirow{2}{*}{$\begin{array}{c}\text { Holotype MNCN } 279718 \\
\text { Measurements }(\mathrm{mm}) \\
\end{array}$} & \multicolumn{3}{|c|}{ Paratypes $n=54$} \\
\hline & & Range & Mean & Standard Deviation \\
\hline SL & 135.6 & $70-170.6$ & 109.9 & 25.2 \\
\hline PrDD & 68.8 & 33.4-85.7 & 56.8 & 12.2 \\
\hline PrPD & 36.2 & $18.6-43.6$ & 28.2 & 6.4 \\
\hline PrVD & 75.6 & $40.2-93.2$ & 59.7 & 14.3 \\
\hline PrAD & 104.9 & $54.7-130.7$ & 84.1 & 22.3 \\
\hline PVL & 39.9 & $19.2-52$ & 32.6 & 8.4 \\
\hline $\mathrm{CPL}$ & 51.3 & $24.2-67.6$ & 41.4 & 10.6 \\
\hline APL & 25.2 & $12.1-32.9$ & 20.5 & 5.0 \\
\hline BD & 34.7 & $18.7-43.6$ & 28.0 & 6.4 \\
\hline BLD & 16.1 & 7.7-18.5 & 12.3 & 2.6 \\
\hline $\mathrm{HL}$ & 33.7 & $17.1-38.8$ & 26.6 & 5.3 \\
\hline PrOL & 12.2 & $6.0-14.4 .1$ & 9.4 & 2.1 \\
\hline ED & 7.7 & $4.2-8.2$ & 5.7 & 1.1 \\
\hline $\mathrm{PsOL}$ & 14.4 & $6.8-19.1$ & 13.7 & 2.4 \\
\hline B1L & 10.0 & $3.6-11.2$ & 7.0 & 1.8 \\
\hline B2L & 14.4 & $4.6-15.6$ & 9.2 & 2.6 \\
\hline PFL & 24.4 & $10.7-30.9$ & 20.2 & 4.3 \\
\hline VFL & 21.5 & $11.5-26$ & 17.6 & 3.5 \\
\hline DFL & 17.8 & $9.1-3.1$ & 15.0 & 3.1 \\
\hline DFH & 24.8 & $11.2-30.6$ & 18.6 & 4.8 \\
\hline AFL & 8.7 & $5.1-26.8$ & 8.6 & 3.0 \\
\hline $\mathrm{AFH}$ & 24.4 & $10.9-31$ & 18.6 & 4.2 \\
\hline CFL & 32.6 & $17.3-40.1$ & 25.7 & 5.3 \\
\hline LL & 44 & $41-47$ & 43.7 & 1.2 \\
\hline RSA & 7.5 & $7.5-8.5$ & 7.6 & 0.2 \\
\hline RSB & 5.5 & $4.5-6.5$ & 5.5 & 0.4 \\
\hline
\end{tabular}


DESCRIPTION: D IV 8, A III 5, P I 15-16, V I 8, C 18; LL 41-47 ( $\bar{x}=43.7$, Median=44), RSA 7.5-8.5 ( $\bar{x}=7.5$, Median=7.5), RSB 4.5-6.5 ( $\bar{x}=5.4$, Median=5.5). Pharyngeal teeth in adults 4.3.2/4.3.2., GR 13-15 $(\bar{x}=14.1 \mathrm{X}=14), \mathrm{VE} 41-43(\bar{x}=42.1, \mathrm{n}=12)$. A mediumsized species, rarely reaching $500 \mathrm{~mm}$. The body is elongated relative to maximum body depth and compared to other Luciobarbus species. The head is large with respect to the body with head length $22-28 \%$ of SL. Infraorbital bones are narrow. The first barbel did not reach the anterior edge of the eye, but, in some specimens, barbels reached the rim of the eye and extended to half the width of the eye. The second barbel usually extended beyond the posterior rim of the eye, rarely reaching the preopercle. The anterior barbel is $19.3-33.3 \%$, and the second $21.2-41 \%$, of HL. The lips are thick with the inferior usually retracted in adults revealing the dentary bone. In some specimens, lips are not retracted and exhibited a well-developed medial lobe. The lacrimal bone has a medium-sized manubrium. The snout is prominent, marked in some specimens, with preorbital length $7.8-10.3 \%$ of SL; postorbital length ranged from 9-13.6\% SL. The iris, as in other Moroccan species of Luciobarbus is yellow pigmented at the superior border but is less conspicuous than in other species. The jugal space closes at the same plane of the vertical of the eye, and 11-12 pores were present in the inferior branch of the pre-operculum. The dorsal fin is posterior on the body with a predorsal distance of 48.2-55.8\% SL. The profile of the dorsal fin is straight or slightly concave, with the last single ray ossified and profusely denticulated (Fig. 7). The caudal peduncle is slightly more elongated than that in Rifian populations, with a height of 30-39.3\% SL. The height of the caudal peduncle is 1.4 to 1.98 times the length of the anal peduncle. The pectoral and ventral fins are longer in males, and the anal fin is longer in the females. Males exhibit nuptial tubercles in the preorbital space. Ventral fins are inserted forward to dorsal fin insertion. The caudal fin is 16.6-27.3\% SL. Morphometric and meristic measurements for the holotype and paratypes of Luciobarbus maghrebensis are represented in Table 7. The coloration of L. maghrebensis is silver-yellowish with darker fins (Fig. 6). Some specimens exhibit a darker longitudinal band in the center of the body. Juveniles present blotches, as in other Luciobarbus species. The skull is wide with a narrow ethmoid bone and a large opercle; the pharyngeal bone is wide with a long inferior process. The lacrimal bone is well developed, and infraorbital bones are narrow. The dentary has a long anterior process, and the maxilla has a small palatine process. The basioccipital plate is wide and triangular.

ETYMOLOGY: The species name "maghrebensis" has been selected because it is mainly distributed in the northwestern area of the Maghreb region.

DISTRIBUTION: This species is endemic to northcentral Morocco, inhabiting Sebou Basin and rivers flowing into the Moulay Bouselham Lagoon on the Atlantic slope (Fig. 1).

COMMON NAME: We propose using the English common name "Maghreb barbel" for this new species.

HABITAT AND BIOLOGY: The species can inhabit rivers of varying typology within its distribution range. Upstream it is substituted for the trout, and in the lower courses of rivers and calm currents it is locally highly abundant. From April to May the species migrates upstream to headwaters for spawning. The species is also present in reservoirs.

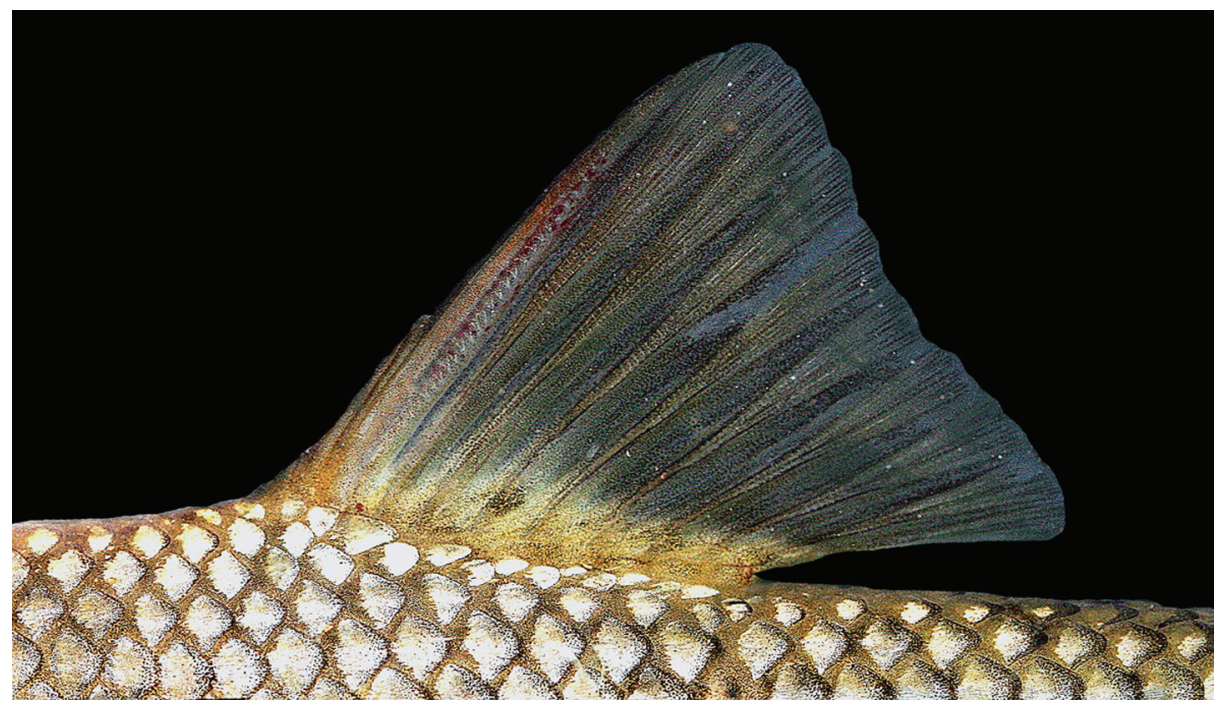

Fig. 7.- Denticulated last single ray of the dorsal fin in specimen of Luciobarbus maghrebensis from the Ifrane River.

Fig. 7.- Aleta dorsal con el ultimo radio sencillo denticulado en un individuo de Luciobarbus maghrebensis del río Ifrane. 
CONSERVATION: Luciobarbus maghrebensis spawning migration has been affected by dams, which present physical barriers to upstream migration. The presences of exotic species in reservoirs, as well as poor water quality in the lower courses, due to fertilizers and pesticides, have probably been primary causes of the decline in its population in recent years. No quantification of the decline in numbers is available, but the species is still abundant and thriving locally. We suggest that this species should be included in the IUCN category of Least Concern (LC).

GENETICS: Uncorrected genetic distances of mitochondrial gene cytb between Luciobarbus maghrebensis and the other analyzed species are represented in Table 6. L. maghrebensis shows 12 diagnostic positions in the cytb gene. A previous allozyme study found three diagnostic loci between $L$ maghrebensis (GP1-2*, GP15* and PGDH-1*) and Grou population (Machordom et al., 1998).

\section{Luciobarbus rifensis Doadrio, Casal-Lopez \& Yahyaoui,} sp. nov.

urn:1sid:zoobank.org:act:F32CCBDD-7C77-4584-889E1DAA0733AF43

TYPE MATERIAL: Holotype: Fig. 8, Table 8. MNCN 290.642; female, 177.2 mm (SL); Laou River, Laou Basin, Derdara, Chefchauen Province, Mediterranean slope in Morocco; (35.118986-5.288900) (Fig. 1); 6/6/2013. Coll: Doadrio, I; Yahyaoui, A; Casal-Lopez, M; Perea, S.

Paratypes: Table 8. MNCN 290.639-641, 290.643-652, 290.655, 290.657-663, 290.665-667: Twenty-four specimens from Laou River, Laou Basin, Derdara, Chefchaouen Province, Mediterranean slope in Morocco; (35.118986, -5.288900); 6/6/2013; Coll: Doadrio, I; Yahyaoui, A; Casal-Lopez, M.; Perea, S. MNCN 284.939-940, 284.942-945, 284.947-948, 284.950-951, 284.953-964: Twentytwo specimens from Laou River, Laou Basin, Beni Ferten, Tétouan Province, Mediterranean slope in Morocco (35.353254, -5.184840); 8/4/2007. Coll: Doadrio, I; Doadrio I jr; Perea, S.
MNCN 280.162-163, 280.165, 280.168, 280.170, 280.172174, 280.176-181, 280.183, 280.185-186; 290.671-696: Fortythree specimens from Loukos River, Loukos Basin, Souk Had, Laghdir, Chefchaouen Province, Atlantic slope in Morocco (35.02624, -5.404660) 30/10/2011. Coll: Doadrio, I; Yahyaoui, A; Casal-Lopez, M; Garzon, P. MNCN 290.707-714, 290.716-722, 290.725-731. Twenty-two specimens from Hachef River, Hachef Basin, Dar Chaoui, Tétouan Province, Atlantic slope in Morocco (35.526763, -5.713771); 6/6/2013. Coll: Doadrio, I; Yahyaoui, A; Casal-Lopez, M; Perea, S.

Holotype and a series of paratypes (112 specimens) have been deposited in the Fish Collection of the Museo Nacional de Ciencias Naturales, Madrid, Spain.

DIAGNOSIS: Differs from other known species of Luciobarbus by the following combination of characters: $42-46$ scales on the lateral line $(\bar{x}=43.9$, Median=44), 8.5-9.5 scales above lateral line $(\bar{x}=8.8$, Median=8.5), and 3.5-5.5 scales below lateral line $(\bar{x}=4.7$, Median=4.5). Insertions of dorsal fin and ventral fin were situated similarly on the body or the insertion of the dorsal fin is slightly anterior to the ventral fin origin. Last single fin ray is ossified and denticulated along its length. The denticulations at mid-height of the ray are shorter than the ray width. In adult specimens, the lower lip is well developed with retracted medial lobe revealing the dentary. The ethmoid bone is wider than long. Vertebrae 41-42, $(\bar{x}=42, \mathrm{n}=12)$; gill rakers $10-15(\bar{x}=13.6$ Median $=13)$. Diagnostic characters of the studied Luciobarbus populations are presented in Table 10.

DESCRIPTION: D IV 8, A III 5, P I 15-16, V I 8, C 18. LL 42-46 $(\bar{x}=43.9$, Median $=44)$; RSA 8.5$9.5(\bar{x}=8.8, \quad$ Median=8.5); RSB 3.5-5.5 $(\bar{x}=4.7$, Median=4.5). Pharyngeal teeth in adults 4.3.2/4.3.2. GR 10-15 ( $\bar{x}=13.6$ Median=13); VE 41-42 $(\bar{x}=42$ $\mathrm{n}=12$ ). A medium-sized species that rarely reaches $500 \mathrm{~mm}$. The body is short and deep in comparison with other Luciobarbus species with maximum body

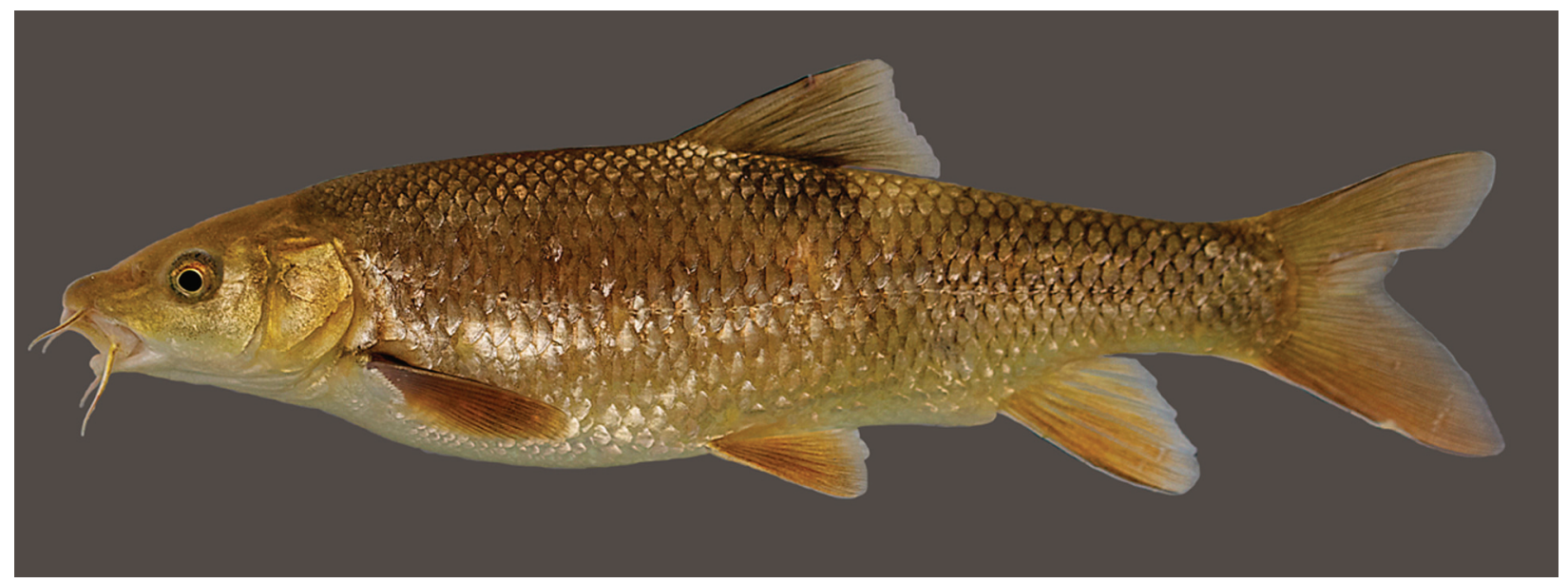

Fig. 8.- Holotype of Luciobarbus rifensis from Laou river, Laou Basin, in Derdara, Morocco. MNCN 290.641.

Fig. 8.- Holotipo de Luciobarbus rifensis del río Laou, Cuenca del Laou, en Derdara, Marruecos. MNCN 290.641. 
Table 8.- Morphometric and meristic measurements of holotype and paratype series of Luciobarbus rifensis.

Tabla 8.- Medidas morfométricas y merísticas del Holotipo y Paratipos de Luciobarbus rifensis.

\begin{tabular}{|c|c|c|c|c|}
\hline \multirow{2}{*}{$\begin{array}{l}\text { Morphometric } \\
\text { variables }\end{array}$} & \multirow{2}{*}{$\begin{array}{c}\text { Holotype MNCN } 290642 \\
\text { Measurement }(\mathrm{mm}) \\
\end{array}$} & \multicolumn{3}{|c|}{ Paratypes $n=111$} \\
\hline & & Range & Mean & Standard Deviation \\
\hline SL & 177.2 & $77.2-226$ & 127.2 & 41.6 \\
\hline PrDD & 90.4 & $41.4-122.8$ & 69.4 & 22.5 \\
\hline PrPD & 45.3 & $20.9-63.3$ & 34.1 & 11.4 \\
\hline PrVD & 94.6 & $43.4-126.2$ & 71.2 & 23.1 \\
\hline $\operatorname{PrAD}$ & 135.3 & $58.4-173.4$ & 98.4 & 32.1 \\
\hline PVL & 50.7 & $21.9-65.4$ & 37.5 & 12.0 \\
\hline $\mathrm{CPL}$ & 68.6 & $26.9-86.0$ & 46.7 & 15.9 \\
\hline APL & 33.2 & $13.2-43.5$ & 23.6 & 8.3 \\
\hline BD & 45.4 & $18.4-58.2$ & 32.5 & 10.6 \\
\hline BLD & 19.1 & $8.4-21.8$ & 13.6 & 3.7 \\
\hline $\mathrm{HL}$ & 41.1 & $19.3-56.7$ & 31.9 & 10.1 \\
\hline $\mathrm{PrOL}$ & 15.7 & $6-20.3$ & 11.2 & 3.5 \\
\hline ED & 7.0 & $3.7-11.4$ & 6.6 & 1.9 \\
\hline $\mathrm{PsOL}$ & 18.6 & $8-27.1$ & 14.4 & 5.0 \\
\hline B1L & 8.1 & $3.0-16.3$ & 7.6 & 3.3 \\
\hline B2L & 13.3 & $4.1-22$ & 10.0 & 4.2 \\
\hline PFL & 28.4 & $12.3-42.2$ & 22.3 & 7.5 \\
\hline VFL & 23.9 & $11.1-32.3$ & 18.5 & 5.5 \\
\hline DFL & 23.2 & $9.5-28.7$ & 16.1 & 4.8 \\
\hline DFH & 31.9 & $11.2-41.9$ & 21.7 & 7.1 \\
\hline AFL & 12.5 & $4.8-17.3$ & 9.4 & 3.1 \\
\hline $\mathrm{AFH}$ & 31.1 & $11.7-42.1$ & 20.8 & 7.7 \\
\hline CFL & 36.7 & $16.2-49.2$ & 26.9 & 8.3 \\
\hline LL & 44 & $42-46$ & 43.8 & 0.8 \\
\hline RSA & 9.5 & $8.5-9.5$ & 8.7 & 0.4 \\
\hline RSB & 5.5 & $3.5-5.5$ & 4.7 & 0.4 \\
\hline
\end{tabular}

depth $22-28 \%$ SL. The head is large with respect to the body with head length $23.2-27.8 \%$ SL. Circumorbital bones are narrow. The barbels were long with the first barbel not reaching the anterior edge of the eye. The second barbel usually extended to the posterior edge of the eye, but did not reach the preopercle. In females, the first barbel is $14.5-36 \% \mathrm{HL}$ and the second $20-40.3 \%$ HL. The lips are thick with the inferior usually retracted in adults making the dentary bone visible. Some specimens do not exhibit inferior lip retraction and show well developed lips (Fig. 9). The lacrimal bone has a short manubrium. The eye is placed anteriorly in the head; preorbital length is 7.1$10.6 \% \mathrm{SL}$, and postorbital length is $10.2-12.5 \% \mathrm{SL}$. The snout is characteristically rounded. The iris, as in other Moroccan species of Luciobarbus, is yellow pigmented at the superior border but is less conspicuous than in other species. The jugal spacious closes at the same vertical plane of the eye and from 11 to 12 pores were present in the inferior branch of the preopercular. The dorsal fin was located posterior on the body, with the predorsal distance being 51.2-55.9\% SL. The profile of the dorsal fin was slightly concave, and presents the last single ray strongly ossified and denticulated. The caudal peduncle (CPL) is high and short with a height of $32.6-39 \% \mathrm{SL}$. The height of the caudal peduncle is 1.2 to 2 times the length of the anal peduncle. The pectoral and ventral fins are longer in males, and the anal fin is longer in females. Males have nuptial tubercles in the preorbital space, but not as well developed as in other Luciobarbus species. Ventral fins are inserted in the same vertical plane as the origin of the dorsal fin or slightly posterior to the dorsal fin. The length of the caudal fin is $14.9-26.5 \%$ SL. Morphometric and meristic measurements for the holotype and the paratypes of the newly described species are represented in Table 8. The coloration of L. rifensis is brown-yellowish with darker fins, with 


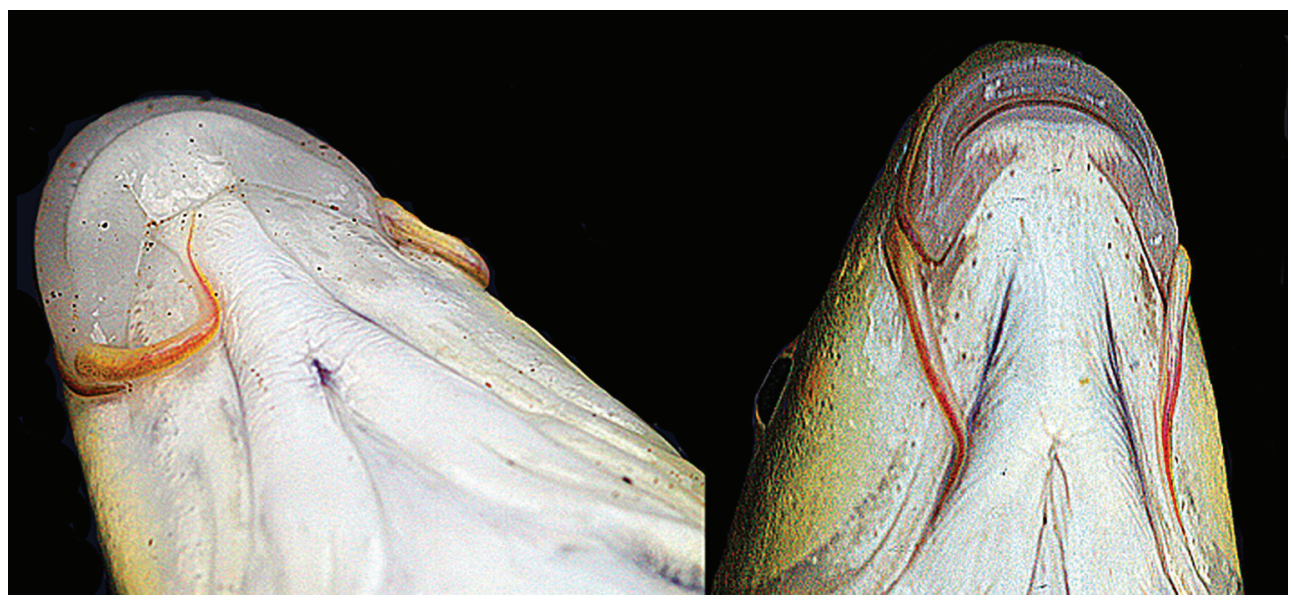

Fig. 9.- Well developed lips with medial lobe in a specimen of Luciobarbus rifensis from the Loukos River on the left and lips retracted revealing dentary in one specimen of Luciobarbus rifensis from Laou River on the right.

Fig. 9.- A la izquierda un individuo de Luciobarbus rifensis del río Loukos con labios bien desarrollados y lóbulo medial. A la derecha un individuo de Luciobarbus rifensis del río Laou con los labios retraídos dejando ver el dentario.

the body becoming progressively paler in the ventral region (Fig. 8). Juveniles present black blotches as in other Luciobarbus species. The skull is long and narrow with a wide ethmoid bone. Infraorbitals are narrow with a large lacrimal bone. The basioccipital plate is triangular. The palatine process of maxilla is small. The superior branch of the pharyngeal bone forms a closed angle with respect to inferior branch.

ETYMOLOGY: The species name "rifensis" has been selected because the distribution range comprises the Rifian Mountains of Morocco.

DISTRIBUTION: The new species is endemic to north Morocco, inhabiting waters from the Loukos Basin on the western Atlantic slope to the Laou Basin on the eastern Mediterranean slope (Fig. 1).

COMMON NAME: We propose the English common name "Rifian barbel" for this newly identified species.

HABITAT AND BIOLOGY: The species is ubiquitous and inhabits streams and rivers with substrata ranging from sandy to stony, being absent only in small streams near the sources of rivers and in shallow waters. The species is present in reservoirs. The spawning period is variable, but usually takes place in April and May. The species migrates upstream to spawn in cold and oxygenated waters where the females excavate a nest in the gravel.

CONSERVATION: Luciobarbus rifensis is a common species. However, its distribution area has been extensively transformed in recent years due to construction of dams, which also hamper upstream migration during the spawning period. In addition, reservoirs can harbor exotic species, some piscivorous, which could be a potential threat to barbels. The area where the species occurs has and increasing interest for tourism activities, which increases water abstraction for recreational use, leading to decreased water levels in summer as well as water oxygen depletion. The species is currently common and locally abundant. For this reason, we suggest that it should be included in the IUCN category as Least Concern (LC).

GENETICS: Uncorrected genetic distance based on mitochondrial gene cytb between Luciobarbus rifensis populations and the other analyzed populations are represented in Table 6. L. rifensis shows 6 diagnostic positions in the cyt $b$ gene. An earlier allozyme study found four diagnostic loci to L. rifensis (MPI, GPI-5, IDHP-2 and CK) with respect to Sebou populations (Machodom et al., 1998).

Luciobarbus rabatensis Doadrio, Perea \& Yahyaoui, sp. nov.

urn:1sid:zoobank.org:act:45CC4380-B532-4AEC-9050692042FF0365

Type Material: Holotype: Fig. 10, Table 9. MNCN 71920, male, 129.9 mm (SL); Grou River, Bou Regreg Basin, Sebt Ait Rahhou, Atlantic slope of Morocco (33.164678, -6.366963) (Fig. 1). Coll: P. Garzón, I. Doadrio, and A. Yahyaoui. 17/04/1991.

Paratypes: MNCN 71725-746, 71918-919, 71921-928; Thirtytwo specimens from the Grou River, Bou Regreg Basin, Sebt Ait Rahhou (33.164678, -6.366963) Morocco. Coll: P. Garzón, I. Doadrio and A. Yahyaoui. 17/04/1991

Holotype and the series of paratypes (33 specimens) have been deposited in the Fish Collection of the Museo Nacional de Ciencias Naturales (Madrid, Spain).

DIAGNOSIS: Differs from other known species of Luciobarbus by the following combination of characters: Number of scales on LL 45-50 ( $\bar{x}=46.5$, Median=46); number of scales above lateral line 


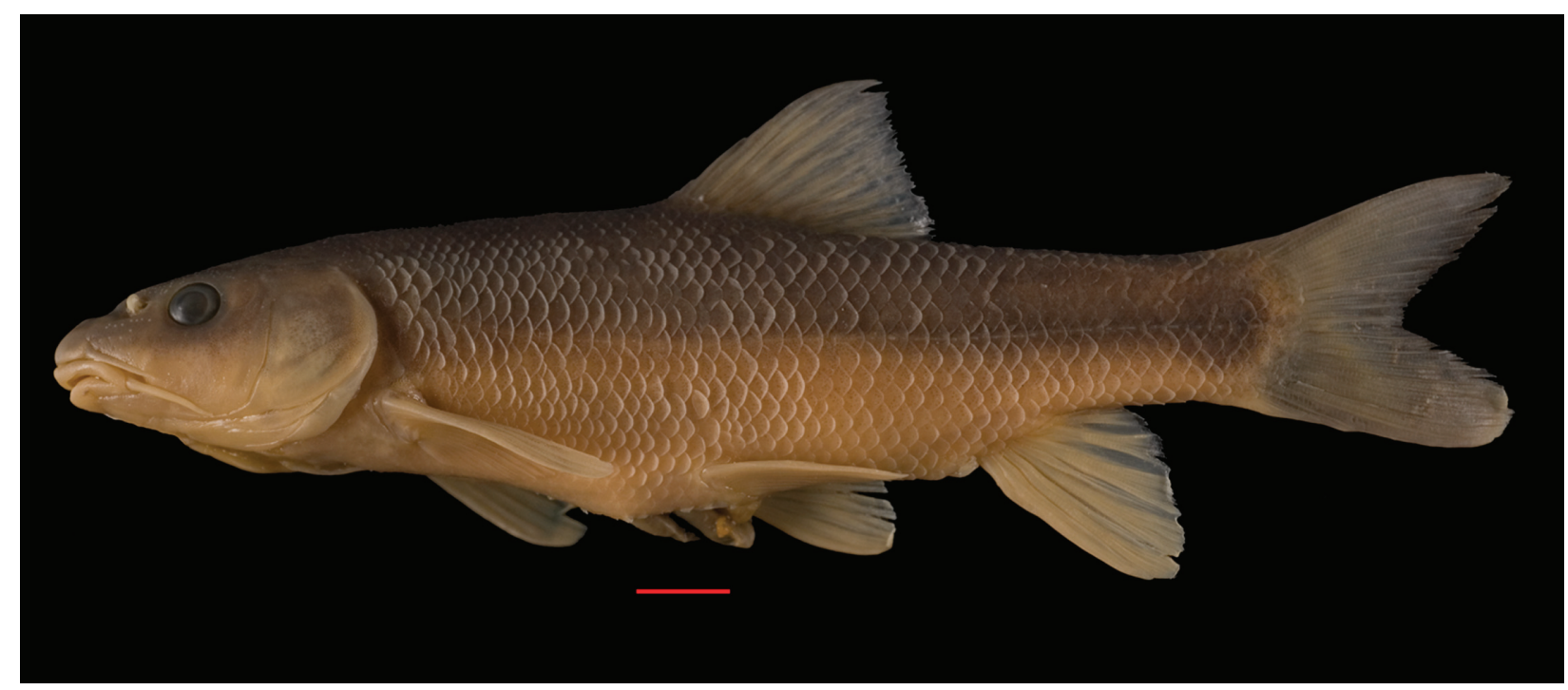

Fig. 10.- Holotype of Luciobarbus rabatensis from Grou River, Bou Regreg Basin, Sebt Ait Rahhou, (Morocco). MNCN 71920. Fig. 10.- Holotipo de Luciobarbus rabatensis del río Grou, cuenca del Bou Regreg en Sebt Ait Rahhou, Marruecos. MNCN 71920.

Table 9.- Morphometric and meristic measurements of holotype and paratypes of Luciobarbus rabatensis.

Tabla 9.- Medidas morfometicas y merísticas del Holotipo y Paratipos de Luciobarbus rabatensis.

\begin{tabular}{|c|c|c|c|c|}
\hline \multirow{2}{*}{$\begin{array}{l}\text { Morphometric } \\
\text { variables }\end{array}$} & \multirow{2}{*}{$\begin{array}{c}\text { Holotype MNCN } 71920 \\
\text { Measurement in mm }\end{array}$} & \multicolumn{3}{|c|}{ Paratypes $\mathrm{n}=32$} \\
\hline & & Range & Mean & Standard Deviation \\
\hline SL & 129.9 & $53.1-113.6$ & 74.8 & 14.5 \\
\hline PrDD & 66.1 & 29.1-59.9 & 40.4 & 7.3 \\
\hline PrPD & 33.8 & $14.4-30.4$ & 19.5 & 4.3 \\
\hline PrVD & 68.2 & $28.8-60.7$ & 39.8 & 8 \\
\hline PrAD & 96.5 & 39.1-84.5 & 55.5 & 10.8 \\
\hline PVL & 34.7 & $14.3-30.8$ & 20.8 & 4 \\
\hline CPL & 49.5 & $18.9-40.5$ & 26.8 & 5.4 \\
\hline APL & 24.7 & $9.1-21.7$ & 13.8 & 2.8 \\
\hline $\mathrm{BD}$ & 31.7 & $14.9-28.8$ & 16.7 & 3.5 \\
\hline BLD & 15.2 & $6.3-14.1$ & 8.9 & 1.8 \\
\hline $\mathrm{HL}$ & 32.1 & $14.2-27.3$ & 18.8 & 3.4 \\
\hline PrOL & 12.8 & $4.1-11-1$ & 6.3 & 1.6 \\
\hline ED & 6.3 & $3.5-5.6$ & 4.4 & 0.6 \\
\hline $\mathrm{PsOL}$ & 16.3 & $6.6-13.7$ & 9.2 & 1.7 \\
\hline B1L & 8.2 & $3.1-6.7$ & 4.6 & 0.8 \\
\hline $\mathrm{B} 2 \mathrm{~L}$ & 9.9 & $4.1-8.4$ & 5.7 & 1.1 \\
\hline PFL & 25.8 & $11.4-22.5$ & 15.4 & 2.7 \\
\hline VFL & 21.6 & $9.2-18.6$ & 12.7 & 2.2 \\
\hline DFL & 16.5 & 7.4-15 & 10.1 & 1.9 \\
\hline DFH & 24.5 & $10.3-21.9$ & 14.3 & 2.8 \\
\hline AFL & 9.3 & $3.7-8.1$ & 5.2 & 1.1 \\
\hline $\mathrm{AFH}$ & 24.3 & $10-21.1$ & 13.9 & 2.5 \\
\hline CFL & 26.5 & $12.7-24$ & 17.1 & 2.7 \\
\hline LL & 46 & $45-50$ & 46.5 & 1.3 \\
\hline RSA & 9.5 & 8.5-10.5 & 9.6 & 0.4 \\
\hline RSB & 6.5 & $6.5-7.5$ & 6.7 & 0.4 \\
\hline
\end{tabular}


8.5-10.5 ( $\bar{x}=9.6$, Median=9.6). Number of scales below lateral line 6.6-7.5 ( $\bar{x}=6.7$, Median=6.5). Insertion of dorsal and ventral fins is in the same vertical plane. Last single fin ray is ossified, with deep denticulations along its length. Denticulations at mid-height of the ray are equal to or longer than ray width. In adult specimens, the inferior lip is retracted revealing the dentary. The ethmoid bone is wider than its length. The maxilla showed a large palatine process. Vertebrae $41-42(\bar{x}=42, \mathrm{n}=6)$; gill rakers $14-12(\bar{x}=12.9)$. Diagnostic characters of the analyzed Luciobarbus populations are presented in Table 10.

DESCRIPTION: D IV 8, A III 5, P I 15-16, V I 8, C 18; LL 46-50 ( $\bar{x}=46.5$, Median=46), RSA 8.5-10.5 ( $\bar{x}=9.6$, Median=9.6), RSB 6.5-7.5 ( $\bar{x}=6.7$, Median=6.5). Pharyngeal teeth in adults 4.3.2/4.3.2. GR 12-14 $(\bar{x}=12.9$ Median=13). VE 41-42 $(\bar{x}=42 \mathrm{n}=6)$. It is a medium-sized species that rarely reaches $500 \mathrm{~mm}$. The body is slightly more elongated in comparison with $L$. rifensis and L. maghrebensis with maximum body depth ranging from $24.4-28.5 \% \mathrm{SL}$. The head is large relative to the body, similar to other Luciobarbus species, with head length 23.5-26.8 \% SL. The preorbital distance is short and the proportion with respect to head length is $29.2-40.5 \% \mathrm{SL}$. The circumorbitals bones are narrow. The barbels are similar in size to those of L. maghrebensis and L. rifensis, but, due to a shorter snout, the first barbel usually reaches the anterior edge of the eye. The second barbel usually extends to the posterior edge of the eye, but does not reach the preopercle. The anterior barbel is $22.1-26.3 \% \mathrm{HL}$ and the second $22.3-32.8 \% \mathrm{HL}$. The lips of adult individuals are usually retracted, and the dentary bone is visible. The lacrimal bone has a short and high manubrium. As in other Moroccan Luciobarbus species, the iris is yellow pigmented at the superior border. The dorsal fin is placed posteriorly on the body with a predorsal lenght of $50.9-56.3 \% \mathrm{SL}$. The profile of the dorsal fin is concave with the last single ray ossified with pronounced denticulation. The caudal peduncle (CPL) is slightly more elongated than in L. maghrebensis and L. rifensis, with a height from 34.7 to $38 \%$ SL. The height of the caudal peduncle is 1.4 to 1.7 times the anal peduncle length. The pectoral and ventral fins are longer in males, and the anal fin is longer in females. Males present nuptial tubercles in the preorbital space. The caudal fin is long, with a lenght of 20.4-24.2\% SL. Morphometric and meristic measurements for the holotype and the paratypes of the newly described species are presented in Table 9. The colour is slightly yellow, brownish in the dorsal region and more silver in the ventral area. The skull is long and narrow with the ethmoid bone wider than its length. The lacrimal bone is short. The basioccipital bone has a wide pentagonal plate. The palatine process of the maxilla is more conspicuous and the pharyngeal bone is narrower than in specimens of the other populations studied.

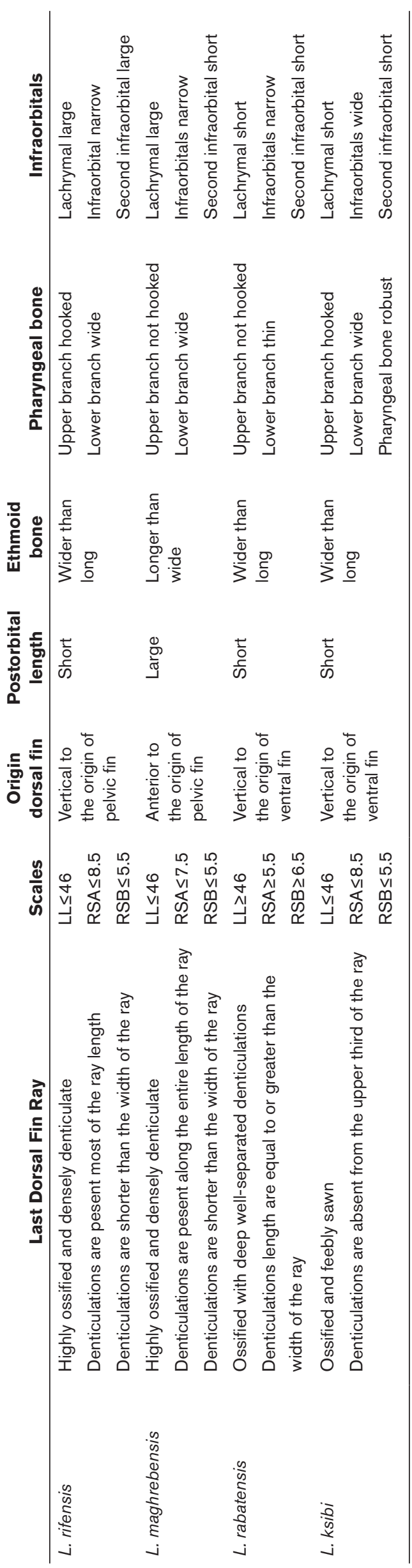


ETYMOLOGY: The species name "rabatensis" has been selected because its distribution area mainly comprises the Bou Regreg Basin, which flows through Rabat City.

DISTRIBUTION: This new species is endemic to north Morocco, inhabiting the Bou Regreg Basin (Fig. 1).

COMMON NAME: We propose the English common name "Rabat barbel" for this species.

HABITAT AND BIOLOGY: As other barbels of Morocco, with the exception of $L$. magniatlantis, L. rabatensis inhabits rivers of differing typologies. The species is present in reservoirs. Spawning takes places at the end of April and the beginning of May. At that time, individuals migrate upstream for spawning in cold and oxygenated waters where the females excavate a nest in the gravel.

CONSERVATION: The habitat of Luciobarbus rabatensis has been extensively transformed with the growth of Rabat City, urban development, water usage, increased pollution linked to agriculture, construction of dams and reservoirs, and introduction of exotic species. Although, an abundant population of this species is still found, it is suffering a slight decline. For this reason, we suggest that this species should be included in the IUCN category of Near Threatened (NT).

GENETICS: Uncorrected genetic distances between Luciobarbus rabatensis and the sister population of Luciobarbus ksibi to mitochondrial gene cytb was $1.7 \%$. Luciobarbus rabatensis shows 6 diagnostic positions in the cyt $b$ gene. A previous allozyme study found one diagnostic locus $(G P I-2 * 118)$ with respect to other African Luciobarbus.

\section{Acknowledgments}

Many persons have participated in the field sampling trips. We warmly thank J. Cubo, M. Merino, J. L. González, P. Garzón, I. Doadrio Jr., A. Doadrio, A. Perdices, Y. Bernat, and S. El Gharbi. We would also like to thank L. Alcaraz, involved in lab work, the curator of the ichthyological collection of National Museum of the Natural Sciences (MNCN-CSIC), G. Solís and also C. Parejo for her technical assistance at the lab of non-destructive techniques with the computerized Tomography scan (CTscan) at the MNCN-CSIC. This project was funded by MESRSFC and the CNRST from Morocco to the Project N ${ }^{\circ} P P R / 2015 / 2$ "Impact des changements climatiques sur la diversité génétique des poissons des eaux douces du Maroc". Permission for fish collection was provided by the High Commissioner for Water, Forest and the Fight Against Dessertification (HCEFLCD) of Morocco.

\section{References}

Akaike, H., 1973. Information theory and an extension of the Maximum Likelihood principle. In: B. N. Petrov \& F. Csaki (eds.). Proceedings of the second International
Symposium on Information Theory. Akademini Kiado. Budapest: 267-281.

Almaça, C., 1966. Sur la systématique des Barbeaux marocaines (Pisces, Cyprinidae, Barbus). Arquivos do Museo Bocage, 7: 111-114.

Almaça, C., 1968. Revision critique de quelques types de Cyprinidés d'Europe et d'Afrique du Nord des collections du Muséum National d'Histoire Naturelle. Bulletin du Muséum National d'Histoire Naturelle, 40: 1116-1144.

Almaça, C., 1970. Sur les barbeaux (genre et sous-genre Barbus) de l'Afrique du Nord. Bulletin du Muséum National d'Histoire Naturelle, 42: 141-158.

Berrebi, P., Kraiem, M. M., Doadrio, I., El Gharbi, S. \& Cattaneo-Berrebi, G., 1995. Ecological and genetic differentiation of Barbus callensis populations in Tunisia. Journal of Fish Biology, 47(5): 850-864. http://dx.doi. org/10.1111/j.1095-8649.1995.tb06007.x

Banarescu, P. \& Bogutskaya N. G., 2003. The Freshwater fishes of Europe. Vol 5/II. Cyprinidae II. Part II: Barbus. Aula Verlag. Wiebelsheim. 454 pp.

Burnaby, T. P., 1966. Growth-invariant discriminant functions and generalized distances. Biometrics, 22: 96-110. http://dx.doi.org/10.2307/2528217

Doadrio, I., 1990. Phylogenetics relationships and classification of western paleartic species of the genus Barbus (Osteichthyes, Cyprinidae). Aquatic Living Resources, 3: 265-282.

Doadrio, I., 1994. Freshwater fish fauna of North Africa and its biogeography. Annals of the Royal Central African Museum (Zoology), 275: 21-34.

Doadrio, I., Bouhadad, R. \& Machordom, A., 1998. Genetic differentiation and biogeography in Saharan populations of the genus Barbus (Osteichthyes, Cyprinidae). Folia Zoologica, 47: 7-20.

Doadrio, I. \& Carmona, J. A., 2003. Testing freshwater Lago Mare Dispersal Theory on the Phylogeny Relationships of Iberian Cyprinid Genera Chondrostoma and Squalius (Cyprinoformes, Cyprinidae). Graellsia, 59(2-3): 457-473. http://dx.doi.org/10.3989/graellsia.2003.v59. i2 -3.260

Doadrio, I., \& Carmona, J. A., 2006. Phylogenetic overview of the genus Squalius (Actinopterygii, Cyprinidae) in the Iberian Peninsula, with description of two new species. Cybium, 30(3): 199-214.

Doadrio, I., Carmona, J. A. \& Machordom, A., 2002. Haplotypes diversity and phylogenetic relationships among the Iberian barbels (Barbus, Cyprinidae) reveal two evolutionary lineages. Journal of Heredity, 93(2): 140-147. http://dx.doi.org/10.1093/jhered/93.2.140

Doadrio, I. \& Elvira, B., 2007. A new species of the genus Achondrostoma Robalo, Almada, Levy \& Doadrio, 2007 (Actinopterygii, Cyprinidae) from western Spain. Graellsia, 63(2): 295-304. http://dx.doi.org/10.3989/ graellsia.2007.v63.i2.96

Doadrio, I., Kottelat, M. \& de Sostoa, A., 2007a. Squalius laietanus, a new species of cyprinid fish from north-eastern Spain and southern France (Teleostei: Cyprinidae). Ichthyological Exploration of Frehwaters, 18(3): 247-256. 
Doadrio, I. \& Madeira, M. J., 2004. A new species of the genus Gobio Cuvier 1816 (Actynopterigii, Cyprinidae) from the Iberian Peninsula and south of France. Graellsia, 60(1): 107-116. http://dx.doi.org/10.3989/ graellsia.2004.v60.i1.197

Doadrio, I., Perea, S. \& Alonso, F., 2007b. A new species of the genus Squalius Bonaparte, 1837 (Actinipterygii, Cyprinidae) from the Tagus River Basin (Central Spain). Graellsia, 63(1): 89-100. http://dx.doi.org/10.3989/ graellsia.2007.v63.i1.83

Geiger, M.F., Herder, F., Monaghan, F. T., Almada, V., Barbieri, R., Bariche, M., Berrebi, P., Bohlen, J., Casal-Lopez, M., Delmastro, G. B., Denys, G. P. J., Dettai, A., Doadrio, I., Kalogianni, E., Kärst, H., Kottelat, A., Kovačić, M., Laporte, M., Lorenzoni, M., Marčić, Z., Özuluğ, M., Perdices, A., Perea, S., Persat, H., Porcelotti, S., Puzzi, C., Robalo, J., Šanda, R., Schneider, M., Šlechtová, V., Stumboudi, M., Walter, S. \& Freyhof, J., 2014. Spatial heterogeneity in the Mediterranean biodiversity hotspot affects barcoding accuracy of its freshwater fishes. Molecular Ecology Resources, 14(6): 1210-1221. http://dx.doi. org/10.1111/1755-0998.12257

Domínguez-Domínguez, O., Pompa-Domínguez, A. \& Doadrio, I., 2007. A new species of the genus Yuriria Jordan \& Evermann, 1896 (Actynopterigii, Cyprinidae) from the Ameca basin of the Central Mexican Plateau. Graellsia, 63(2): 259-271. http://dx.doi.org/10.3989/ graellsia.2007.v63.i2.93

Domínguez-Domínguez, O., Pérez-Rodríguez, R., EscaleraVázquez, L. H. \& Doadrio, I., 2009. Two new species of the genus Notropis Rafinesque, 1817 (Actinopterygii, Cyprinidae) from the Lerma River Basin in Central Mexico. Hidrobiológica, 19(2): 159-172.

Griffiths, H. I., Krystufec, B. \& Reed, J. M., 2004. Balkan Biodiversity Pattern and Process in the European Hotspot. Kluwer Academic Publisher. Dordrecht. 361 pp.

Karaman, M. S., 1971. Süsswasserfische der Türkei. 8. Teil: Revision der Barben Europas, Vorderasiens und Nordafrikas. Mitteilungen aus dem Hamburgischen Zoologischen Museum und Institut, 67: 175-254.

Kottelat, M. \& Freyhof, J., 2007. Handbook of European freshwater fishes. Cornol. Berlin. 646 pp.

Machordom, A., Bouhadad, I. \& Doadrio, I., 1998. Allozyme variation and evolutionary history of North African populations of the genus Barbus (Osteichthyes, Cyprinidae). Diversity and Distributions, 4: 217-234.

Machordom, A. \& Doadrio, I., 1993. Phylogenie et taxonimie des barbeaux nord-africanes. Cahiers d'Ethologie, 13(2): 218.

Machordom, A., Doadrio, I. \& Berrebi, P., 1995. Phylogeny and evolution of the genus Barbus in the Iberian Peninsula as revealed by allozyme electrophoresis. Journal of Fish Biology, 47(2): 211-236. http://dx.doi. org/10.1111/j.1095-8649.1995.tb01890.x

Machordom, A. \& Doadrio, I., 2001a. Evolutionary history and speciation modes in the cyprinid genus Barbus. Proceedings of the Royal Society of London. Series B: Biological Sciences, 268(1473): 1297-1306. http:// dx.doi.org/10.1098/rspb.2001.1654
Machordom, A. \& Doadrio, I., 2001b. Evidence of a Cenozoic-Betic-Kabilian connection based on freshwater fish phylogeography (Luciobarbus, Cyprinidae). Molecular Phylogenetics and Evolution, 18(2): 252-263. http://dx.doi.org/10.1006/mpev.2000.0876

Pellegrin, J., 1920. Poissons du Maroc recueillis par M. Ch. Alluaud. Bulletin du Muséum National d'Histoire Naturelle, 26(7): 612-613.

Pellegrin, J., 1922. Poissons recueillis par M. Ch. Alluaud dans la région du Sous (Maroc). Bulletin de la Société des sciences naturelles du Maroc, 2: 103-106.

Posada, D., 2008. jModelTest: Phylogenetic Model Averaging. Molecular Biology and Evolution, 25(7): 1253-1256. http://dx.doi.org/10.1093/molbev/msn083

Robalo, J. I., Almada, V. C., Sousa Santos, C., Moreira, M. I. \& Doadrio, I., 2005. New species of the genus Chondrostoma Agassiz, 1832 (Actynopterigii, Cyprinidae) from western Portugal. Graellsia, 61(1): 15-28. http:// dx.doi.org/10.3989/graellsia.2005.v61.i1.3

Rohlf, F. J., 2003. TpsDig, Digitize Landmarks and Outlines. Department of Ecology and Evolution, State University of New York. Stony Brook.

Rohlf, F. J. \& Bookstein, F. L., 1987. A comment on shearing as a method for "size correction". Systematic Zoology, 36(4): 356-367. http://dx.doi.org/10.2307/2413400

Ronquist, F., Teslenko, M., van der Mark, P., Ayres, D. L., Darling, A., Höhna, S., Larget, B., Liu, L., Suchard, M. A. \& Huelsenbeck, J. P., 2012. MrBayes 3.2: Efficient Bayesian Phylogenetic Inference and Model Choise Across Large Model Space. Systematic Biology, 61(3): 539-542. http://dx.doi.org/10.1093/sysbio/sys029

Tamura, K., Stecher, G., Peterson, D., Filipski, A. \& Kumar, S., 2013. MEGA6: Molecular Evolutionary Genetics Analysis (MEGA) Software version 6.0. Molecular Biology and Evolution, 24(8): 1596-1599. http://dx.doi. org $/ 10.1093 / \mathrm{molbev} / \mathrm{mst} 197$

Tsigenopoulos, C. S., Durand, J. D., Ünlu, E. \& Berrebi, P., 2003. Rapid radiation of the Mediterranean Barbus species (Cyprinidae) after the Messinian Salinity Crisis of the Mediterranean Sea, inferred from mitochondrial phylogenetic analysis. Biological Journal of the Linnean Society, 80(2): 207-222. http://dx.doi. org/10.1046/j.1095-8312.2003.00237.x

Yang, L., Sado, T., Vincent Hirt, M., Pasco-Viel, E., Arunachalam, M., Li, J., Wang, X., Freyhof, J., Saitoh, K., Simons, A. M., Miya, M., He, S. \& Mayden, R. L., 2015. Phylogeny and polyploidy: resolving the classification of cyprinine fishes (Teleostei: Cypriniformes). Molecular Phylogenetics and Evolution, 85: 97-116. http://dx.doi.org/10.1016/j.ympev.2015.01.014

Zardoya, R. \& Doadrio, I., 1999. Molecular evidence on the evolutionary and biogeographical patterns of European cyprinids. Journal of Molecular Evolution, 49(2): 227-237. http://dx.doi.org/10.1007/PL00006545

Zardoya, R., Economidis, P. S. \& Doadrio, I., 1999. Phylogenetic relationshipes of Greek Cyprinidae: molecular evidence for at least two origins of the Greek cyprinid fauna. Molecular Phylogenetics and Evolution, 13(1): 122-131. http://dx.doi.org/10.1006/mpev. 1999.0630 
Appendix 1.- Kruskal-Wallis test and Non-parametric Mann-Whitney's pairwise comparisons for all populations. Values of Kruskal-Wallis test $(\mathrm{H})$ below variables. Values of Mann-Whitney test are below the diagonal. Median in the diagonal of each variable. Significant differences $p<0.05\left(^{*}\right) ; p<0.01\left(^{* *}\right)$. Acronyms are defined in the Material and Methods.

Apéndice 1.- Test de Kruskal-Wallis y análisis no paramétrico de Mann-Whitney para todas las poblaciones. Valores para el test de Kruskal-Wallis $(\mathrm{H})$ debajo de las variables. Valores de Mann-Whitney por debajo de la diagonal. Valor de la Mediana en la diagonal de cada variable. Diferencias significativas $p<0,05\left(^{*}\right) ; p<0,01\left(^{* *}\right)$. Las abreviaturas están descritas en el epígrafe de Material y Métodos.

\begin{tabular}{|c|c|c|c|c|c|}
\hline Variables & Populations & Rif $(n=112)$ & Sebou $(n=55)$ & Bou Regreg $(n=33)$ & L. ksibi $(n=23)$ \\
\hline \multirow[t]{4}{*}{$\mathrm{SL}\left(\mathrm{H}=65.99^{\star \star}\right)$} & Rif & 140.46 & & & \\
\hline & Sebou & $0.018^{\star}$ & 106.13 & & \\
\hline & Bou-Regreg & $<0.0001^{\star \star}$ & $<0.0001^{\star \star}$ & 71.88 & \\
\hline & Kasab & $<0.0001^{\star *}$ & $0.005^{\star \star}$ & $0.0006^{\star *}$ & 88.97 \\
\hline \multirow{4}{*}{$\begin{array}{l}\text { SL/PrDD } \\
\left(\mathrm{H}=55.87^{\star \star}\right)\end{array}$} & Rif & 1.876 & & & \\
\hline & Sebou & $<0.0001^{\star *}$ & 1.934 & & \\
\hline & Bou-Regreg & $0.005^{\star}$ & $<0.0001^{\star \star}$ & 1.843 & \\
\hline & Kasab & 0.206 & $<0.0001^{\star *}$ & 0.624 & 1.863 \\
\hline \multirow{4}{*}{$\begin{array}{l}\text { SL/PrPD } \\
\left(H=20.44^{\star \star}\right)\end{array}$} & Rif & 3.768 & & & \\
\hline & Sebou & $<0.001^{\star *}$ & 3.682 & & \\
\hline & Bou-Regreg & $0.021^{*}$ & 0.379 & 3.818 & \\
\hline & Kasab & $0.002^{\star \star}$ & 0.8084 & 0.34 & 3.88 \\
\hline \multirow{4}{*}{$\begin{array}{l}\text { SL/PrVD } \\
\left(H=97.1^{\star \star}\right)\end{array}$} & Rif & 1.793 & & & \\
\hline & Sebou & $<0.0001^{\star \star}$ & 1.828 & & \\
\hline & Bou-Regreg & $<0.0001^{\star *}$ & $<0.0001^{\star \star}$ & 1.87 & \\
\hline & Kasab & $<0.0001^{\star \star}$ & $<0.0001^{\star \star}$ & $<0.0001^{\star}$ & 1.919 \\
\hline \multirow{4}{*}{$\begin{array}{l}\text { SL/PrAD } \\
\left(\mathrm{H}=86.63^{\star \star}\right)\end{array}$} & Rif & 1.304 & & & \\
\hline & Sebou & 0.183 & 1.311 & & \\
\hline & Bou-Regreg & $<0.0001^{\star *}$ & $<0.0001^{\star \star}$ & 1.346 & \\
\hline & Kasab & $<0.0001^{\star \star}$ & $<0.0001^{\star \star}$ & 0.938 & 1.347 \\
\hline \multirow{4}{*}{$\begin{array}{l}\text { PrVD/PrDD } \\
\left(H=89.65^{\star \star}\right)\end{array}$} & Rif & 1.045 & & & \\
\hline & Sebou & 0.051 & 1.065 & & \\
\hline & Bou-Regreg & $<0.0001^{\star \star}$ & $<0.0001^{\star \star}$ & 0.981 & \\
\hline & Kasab & $<0.0001^{\star \star}$ & $<0.0001^{\star \star}$ & $0.02^{*}$ & 0.964 \\
\hline \multirow{4}{*}{$\begin{array}{l}\text { SL/PVL } \\
\left(H=22.62^{\star *}\right)\end{array}$} & Rif & 3.474 & & & \\
\hline & Sebou & 0.277 & 3.415 & & \\
\hline & Bou-Regreg & $0.002^{\star \star}$ & $<0.0001^{\star \star}$ & 3.601 & \\
\hline & Kasab & $0.005^{\star \star}$ & $<0.0001^{\star \star}$ & 0.414 & 3.63 \\
\hline \multirow{4}{*}{$\begin{array}{l}\text { SL/CPL } \\
\left(\mathrm{H}=41.94^{\star \star}\right)\end{array}$} & Rif & 2.818 & & & \\
\hline & Sebou & $<0.0001^{\star *}$ & 2.699 & & \\
\hline & Bou-Regreg & 0.301 & $<0.0001^{\star \star}$ & 2.798 & \\
\hline & Kasab & 0.928 & $<0.0001^{\star *}$ & 0.481 & 2.804 \\
\hline \multirow{4}{*}{$\begin{array}{l}\text { SL/APL } \\
\left(H=19.43^{\star \star}\right)\end{array}$} & Rif & 5.561 & & & \\
\hline & Sebou & 0.648 & 5.587 & & \\
\hline & Bou-Regreg & $0.003^{\star \star}$ & 0.06 & 5.39 & \\
\hline & Kasab & $<0.0001^{\star *}$ & $0.003^{\star *}$ & 0.093 & 5.31 \\
\hline \multirow{4}{*}{$\begin{array}{l}\text { CPL/BLD } \\
\left(\mathrm{H}=68.72^{\star \star}\right)\end{array}$} & Rif & 3.275 & & & \\
\hline & Sebou & 0.662 & 3.187 & & \\
\hline & Bou-Regreg & $<0.0001^{\star *}$ & $<0.0001^{\star *}$ & 3.003 & \\
\hline & Kasab & $<0.0001^{\star \star}$ & $<0.0001^{\star *}$ & $<0.0001^{\star *}$ & 2.773 \\
\hline \multirow{4}{*}{$\begin{array}{l}\text { APL/BLD } \\
(\mathrm{H}=27.44)\end{array}$} & Rif & 1.642 & & & \\
\hline & Sebou & $0.008^{\star \star}$ & 1.576 & & \\
\hline & Bou-Regreg & $<0.0001^{\star \star}$ & 0.205 & 1.546 & \\
\hline & Kasab & $<0.0001^{\star *}$ & 0.006 & $0.04^{*}$ & 1.495 \\
\hline
\end{tabular}


Appendix 1.- (continued)

\begin{tabular}{|c|c|c|c|c|c|}
\hline Variables & Populations & $\operatorname{Rif}(n=112)$ & Sebou $(n=55)$ & Bou Regreg $(n=33)$ & L. ksibi $(\mathrm{n}=23)$ \\
\hline \multirow[t]{4}{*}{ SL/BD $(H=44.26)$} & Rif & 3.999 & & & \\
\hline & Sebou & 0.752 & 3.991 & & \\
\hline & Bou-Regreg & $<0.0001^{\star \star}$ & $<0.0001^{* *}$ & 3.829 & \\
\hline & Kasab & $<0.0001^{\star \star}$ & $<0.0001^{* *}$ & 0.2001 & 3.75 \\
\hline \multirow{4}{*}{$\begin{array}{l}\text { SL/BLD } \\
\left(\mathrm{H}=44.76^{\star *}\right)\end{array}$} & Rif & 9.061 & & & \\
\hline & Sebou & 0.752 & 8.719 & & \\
\hline & Bou-Regreg & $<0.0001^{\star \star}$ & $<0.0001^{\star *}$ & 8.378 & \\
\hline & Kasab & $<0.0001^{\star \star}$ & $<0.0001^{\star \star}$ & 0.2 & 7.891 \\
\hline \multirow[t]{4}{*}{$\mathrm{SL} / \mathrm{HL}\left(\mathrm{H}=10.4^{*}\right)$} & Rif & 3.981 & & & \\
\hline & Sebou & 0.145 & 4.044 & & \\
\hline & Bou-Regreg & 0.89 & 0.107 & 3.992 & \\
\hline & Kasab & $<0.0001^{\star \star}$ & $<0.0001^{\star \star}$ & $<0.0001^{\star *}$ & 3.811 \\
\hline \multirow{4}{*}{$\begin{array}{l}\mathrm{HL} / \mathrm{PrOL} \\
(\mathrm{H}=27.43)\end{array}$} & Rif & 2.73 & & & \\
\hline & Sebou & $0.044^{*}$ & 2.788 & & \\
\hline & Bou-Regreg & $<0.0001^{\star \star}$ & $0.0007^{\star \star}$ & 2.98 & \\
\hline & Kasab & 0.397 & 0.624 & $0.002^{\star \star}$ & 2.77 \\
\hline \multirow{4}{*}{$\begin{array}{l}\mathrm{HL} / \mathrm{PsOL} \\
\left(\mathrm{H}=151.5^{\star \star}\right)\end{array}$} & Rif & 2.205 & & & \\
\hline & Sebou & $<0.0001^{\star \star}$ & 1.606 & & \\
\hline & Bou-Regreg & $<0.0001^{\star \star}$ & $<0.0001^{\star \star}$ & 2.025 & \\
\hline & Kasab & 0.67 & $<0.0001^{* *}$ & $<0.0001^{\star *}$ & 2.187 \\
\hline \multirow[t]{4}{*}{$\mathrm{SL} / \operatorname{PrOL}\left(36.47^{\star \star}\right)$} & Rif & 10.965 & & & \\
\hline & Sebou & $0.002^{\star \star}$ & 11.364 & & \\
\hline & Bou-Regreg & $<0.0001^{\star \star}$ & $<0.0001^{\star *}$ & 12.06 & \\
\hline & Kasab & 0.701 & $<0.0001^{\star *}$ & $<0.0001^{\star *}$ & 11.122 \\
\hline \multirow[t]{4}{*}{ SL/PsOL $\left(153.8^{\star \star}\right)$} & Rif & 8.867 & & & \\
\hline & Sebou & $<0.0001^{\star \star}$ & 6.491 & & \\
\hline & Bou-Regreg & $<0.0001^{\star \star}$ & $<0.0001^{\star \star}$ & 8.127 & \\
\hline & Kasab & 0.14 & $<0.0001^{\star \star}$ & $<0.0001^{\star \star}$ & 8.622 \\
\hline \multirow{4}{*}{$\begin{array}{l}\mathrm{PsOL} / \mathrm{PrOL} \\
(\mathrm{H}=153.9)\end{array}$} & Rif & 1.248 & & & \\
\hline & Sebou & $<0.0001^{\star *}$ & 1.727 & & \\
\hline & Bou-Regreg & $<0.0001^{\star \star}$ & $<0.0001^{\star *}$ & 1.462 & \\
\hline & Kasab & 0.745 & $<0.0001^{\star \star}$ & $<0.0001^{\star \star}$ & 1.265 \\
\hline \multirow[t]{4}{*}{ SL/ED $\left(H=51.66^{\star \star}\right)$} & Rif & 20.004 & & & \\
\hline & Sebou & 0.936 & 19.71 & & \\
\hline & Bou-Regreg & $<0.0001^{\star \star}$ & $<0.0001^{\star *}$ & 17.1 & \\
\hline & Kasab & $0.004^{\star \star}$ & $0.009^{\star *}$ & 0.303 & 17.37 \\
\hline \multirow{4}{*}{$\begin{array}{l}\mathrm{HL/L1B} \\
\left(\mathrm{H}=22.49^{\star \star}\right)\end{array}$} & Rif & 4.032 & & & \\
\hline & Sebou & 0.29 & 3.9 & & \\
\hline & Bou-Regreg & 0.546 & $0.011^{*}$ & 4.06 & \\
\hline & Kasab & $0.0005^{\star \star}$ & $0.0002^{\star *}$ & $<0.0001^{\star *}$ & 3.545 \\
\hline \multirow{4}{*}{$\begin{array}{l}\mathrm{PrO} / \mathrm{L} 1 \mathrm{~B} \\
\left(\mathrm{H}=16.57^{\star \star}\right)\end{array}$} & Rif & 1.459 & & & \\
\hline & Sebou & 0.114 & 1.419 & & \\
\hline & Bou-Regreg & 0.095 & 0.365 & 1.359 & \\
\hline & Kasab & $0.0005^{\star \star}$ & $0.001^{* *}$ & $0.007^{\star \star}$ & 1.293 \\
\hline \multirow{4}{*}{$\begin{array}{l}\mathrm{HL} / \mathrm{L} 2 \mathrm{~B} \\
\left(\mathrm{H}=48.31^{\star *}\right)\end{array}$} & Rif & 3.154 & & & \\
\hline & Sebou & $0.037^{\star}$ & 3.001 & & \\
\hline & Bou-Regreg & 0.085 & 0.0001 & 3.29 & \\
\hline & Kasab & $<0.0001^{\star \star}$ & $<0.0001^{\star *}$ & $<0.0001^{\star \star}$ & 2.571 \\
\hline
\end{tabular}


Appendix 1.- (continued)

\begin{tabular}{|c|c|c|c|c|c|}
\hline Variables & Populations & Rif $(n=112)$ & Sebou $(n=55)$ & Bou Regreg $(n=33)$ & L. ksibi $(\mathrm{n}=23)$ \\
\hline \multirow{4}{*}{$\begin{array}{l}\mathrm{PsOL} / \mathrm{L} 2 \mathrm{~B} \\
\left(\mathrm{H}=122.3^{\star \star}\right)\end{array}$} & Rif & 1.434 & & & \\
\hline & Sebou & $<0.0001^{\star \star}$ & 1.872 & & \\
\hline & Bou-Regreg & $0.0003^{\star \star}$ & $<0.0001^{\star *}$ & 1.612 & \\
\hline & Kasab & $<0.0001^{\star \star}$ & $<0.0001^{\star \star}$ & $<0.0001^{\star \star}$ & 1.17 \\
\hline \multirow{4}{*}{$\begin{array}{l}\text { HL/PFL } \\
\left(\mathrm{H}=104.1^{\star \star}\right)\end{array}$} & Rif & 1.43 & & & \\
\hline & Sebou & $<0.0001^{\star *}$ & 1.318 & & \\
\hline & Bou-Regreg & $<0.0001^{\star \star}$ & $<0.0001^{\star *}$ & 1.221 & \\
\hline & Kasab & $<0.0001^{* \star}$ & $<0.0001^{\star *}$ & 0.104 & 1.179 \\
\hline \multirow{4}{*}{$\begin{array}{l}\mathrm{HL} / \mathrm{VFL} \\
\left(\mathrm{H}=133.2^{\star \star}\right)\end{array}$} & Rif & 1.721 & & & \\
\hline & Sebou & $<0.0001^{\star *}$ & 1.524 & & \\
\hline & Bou-Regreg & $<0.0001^{\star \star}$ & 0.2194 & 1.489 & \\
\hline & Kasab & $<0.0001^{\star \star}$ & $<0.0001^{\star \star}$ & $<0.0001^{\star *}$ & 1.352 \\
\hline \multirow{4}{*}{$\begin{array}{l}\mathrm{HL} / \mathrm{CFL} \\
\left(\mathrm{H}=78.93^{\star \star}\right)\end{array}$} & Rif & 1.185 & & & \\
\hline & Sebou & $<0.0001^{\star \star}$ & 1.032 & & \\
\hline & Bou-Regreg & $<0.0001^{\star \star}$ & $<0.0001^{\star \star}$ & 1.09 & \\
\hline & Kasab & $<0.0001^{\star \star}$ & 0.933 & $0.006^{\star \star}$ & 1.028 \\
\hline \multirow[t]{4}{*}{$\operatorname{LL}\left(\mathrm{H}=72.21^{\star \star}\right)$} & Rif & 44 & & & \\
\hline & Sebou & 0.1428 & 44 & & \\
\hline & Bou-Regreg & $<0.0001^{\star \star}$ & $<0.0001^{\star \star}$ & 46 & \\
\hline & Kasab & 0.605 & 0.681 & $0^{\star \star}$ & 44 \\
\hline \multirow[t]{4}{*}{$\operatorname{RSA}\left(H=145.8^{\star \star}\right)$} & Rif & 8.5 & & & \\
\hline & Sebou & $<0.0001^{\star \star}$ & 7.5 & & \\
\hline & Bou-Regreg & $<0.0001^{\star \star}$ & $<0.0001^{\star \star}$ & 9.5 & \\
\hline & Kasab & $0.0004^{\star \star}$ & $<0.0001^{\star *}$ & $<0.0001^{\star *}$ & 8.5 \\
\hline \multirow[t]{4}{*}{$\operatorname{RSB}\left(H=123.7^{\star \star}\right)$} & Rif & 4.5 & & & \\
\hline & Sebou & $<0.0001^{\star *}$ & 5.5 & & \\
\hline & Bou-Regreg & $<0.0001^{\star \star}$ & $<0.0001^{\star \star}$ & 6.5 & \\
\hline & Kasab & 0.025 & $<0.0001^{\star \star}$ & $<0.0001^{\star \star}$ & 4.5 \\
\hline
\end{tabular}


Appendix 2.- Osteological features.

Apéndice 2.- Características osteológicas.

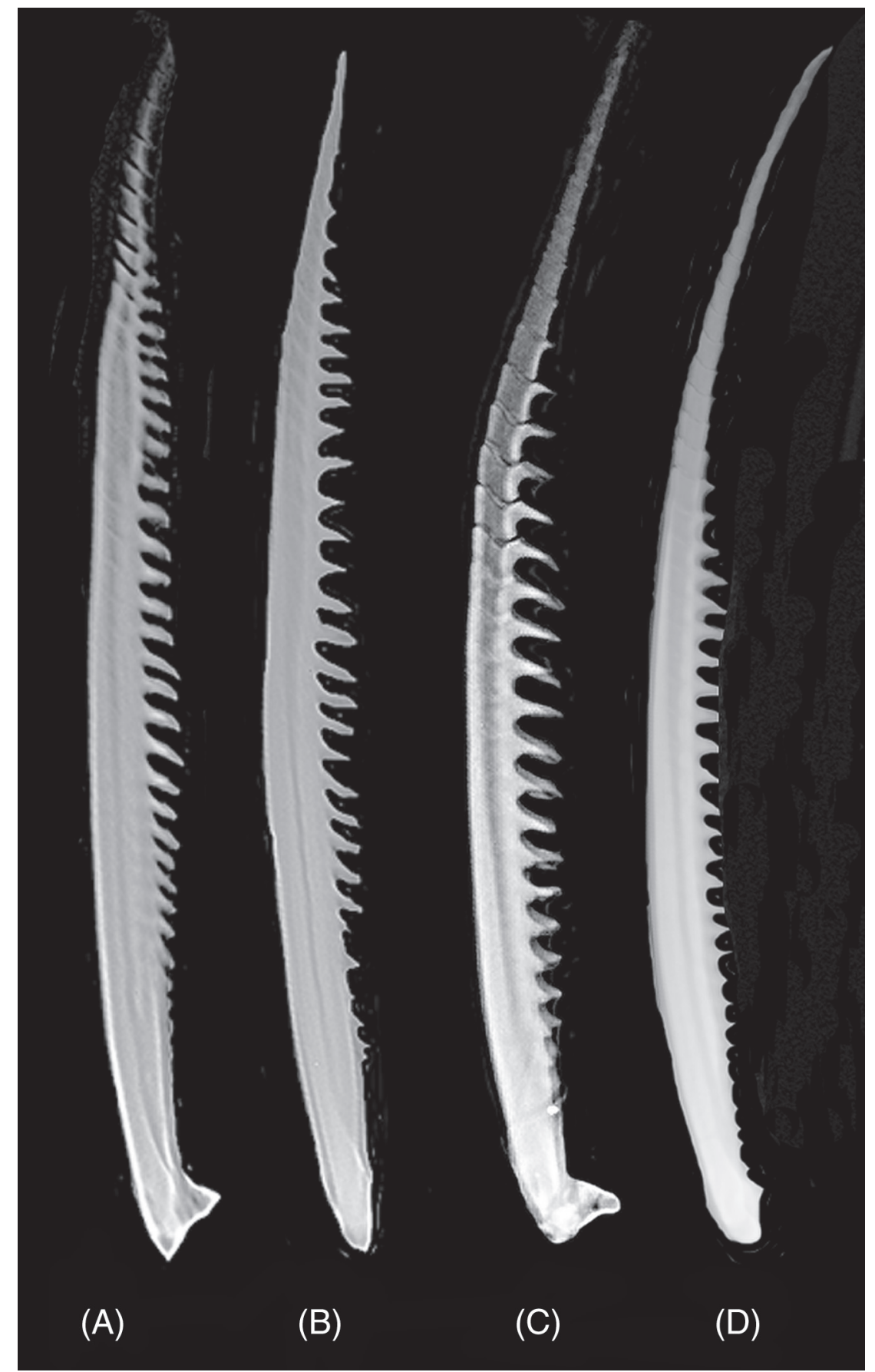

Appendix 2-1.- Last single dorsal fin ray in adult specimens (SL>120 mm) of the studied populations. A: Rifian population (Laou River). B: Sebou Basin (Ifrane River). C: Bou Regreg (Grou River). D: Luciobarbus ksibi (Kasab River).

Apéndice 2-1.- Último radio sencillo de la aleta dorsal en individuos adultos ( $S L>120 \mathrm{~mm}$ ) de las diferentes poblaciones estudiadas. A: población del Rif (río Laou). B: Cuenca del Sebou (río Ifrane). C: Cuenca del Bou Regreg (río Grou). D: Luciobarbus ksibi (río Kasab). 


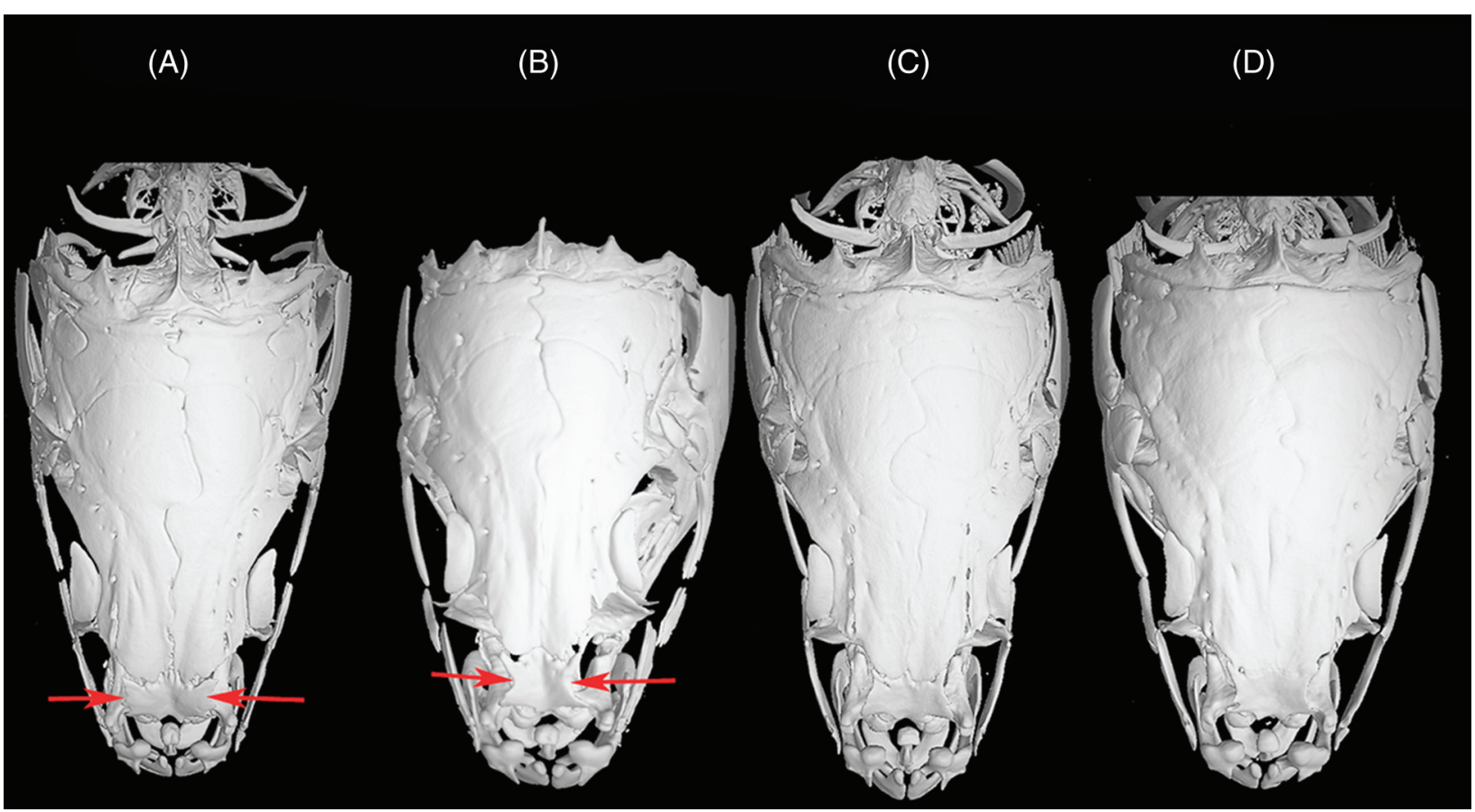

Appendix 2-2.- Dorsal view of the skull of the populations under study. Arrows indicate width of the ethmoid bone. A: Rifian population (Laou River) B: Sebou Basin (Ifrane River) C: Bou Regreg (Grou River), D: Luciobarbus ksibi (Kasab River).

Apéndice 2-2.- Cráneo de las diferentes poblaciones estudiadas. Entre flechas se señala la diferente anchura del etmoides. A: población del Rif (río Laou). B: Cuenca del Sebou (río Ifrane). C: Cuenca del Bou Regreg (río Grou). D: Luciobarbus ksibi (río Kasab).

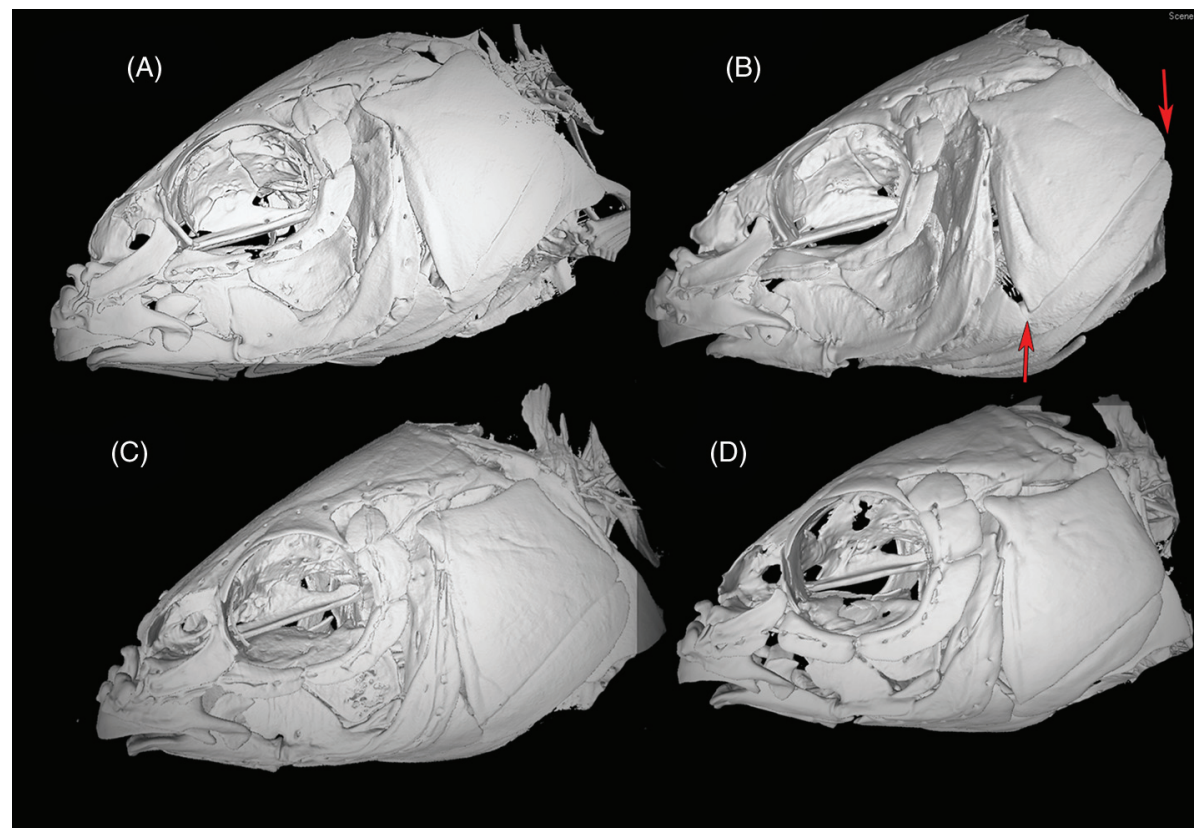

Appendix 2-3.- Lateral view of the skull of the studied populations. Arrows show the length of the opercular bone. A: Rifian population (Laou River). B: Sebou Basin (Ifrane River). C: Bou Regreg (Grou River). D: Luciobarbus ksibi (Kasab River).

Apéndice 2-3.- Cráneo de las diferentes poblaciones estudiadas. Entre flechas se muestra la longitud del opercular. A: población del Rif (río Laou). B: Cuenca del Sebou (río Ifrane). C: Cuenca del Bou Regreg (río Grou). D: Luciobarbus ksibi (río Kasab). 


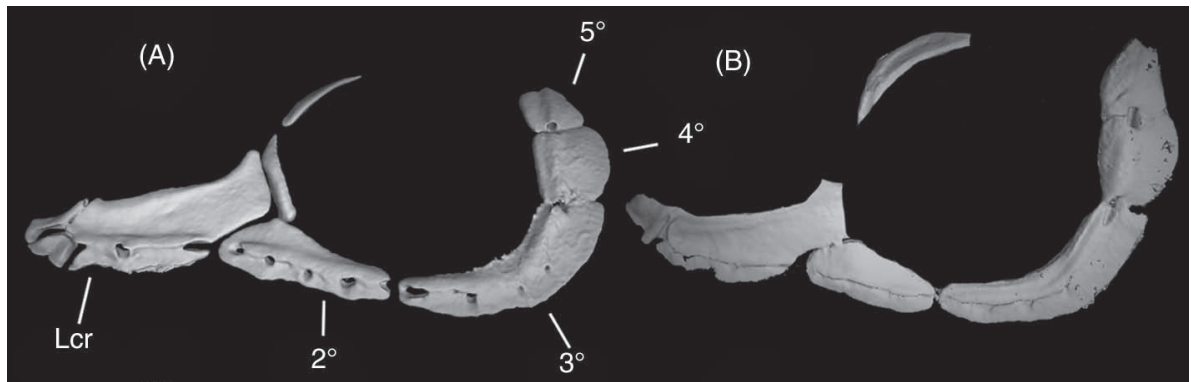

(C)

(D)
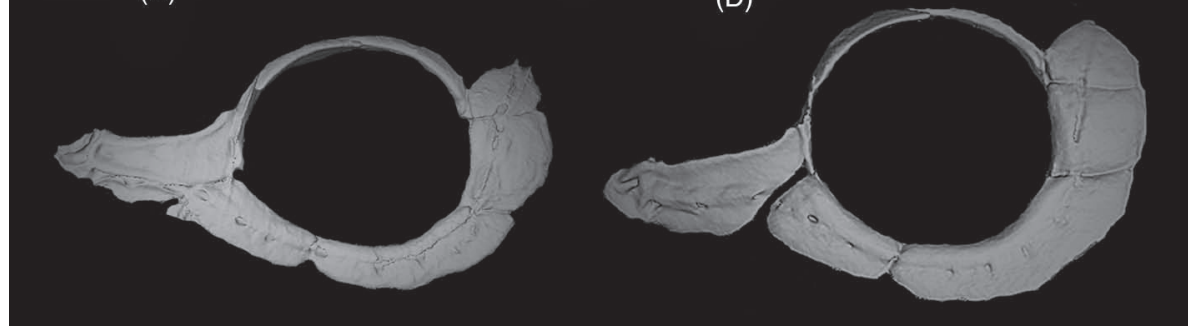

Appendix 2-4.- Infraorbital bones of the studied populations. A: Rifian population (Laou River). B: Sebou Basin (Ifrane River). C: Bou Regreg (Grou River). D: Luciobarbus ksibi (Kasab River). Lcr = Lacrymal. $2^{\circ}-5^{\circ}$ : Infraorbitals.

Apéndice 2-4.- Huesos infraorbitarios de las diferentes poblaciones estudiadas. A: población del Rif (río Laou). B: Cuenca del Sebou (río Ifrane). C: Bou Regreg (río Grou). D: Luciobarbus ksibi (río Kasab). Lcr: Lacrimal. $2^{\circ}-5^{\circ}$ Infraorbitales.

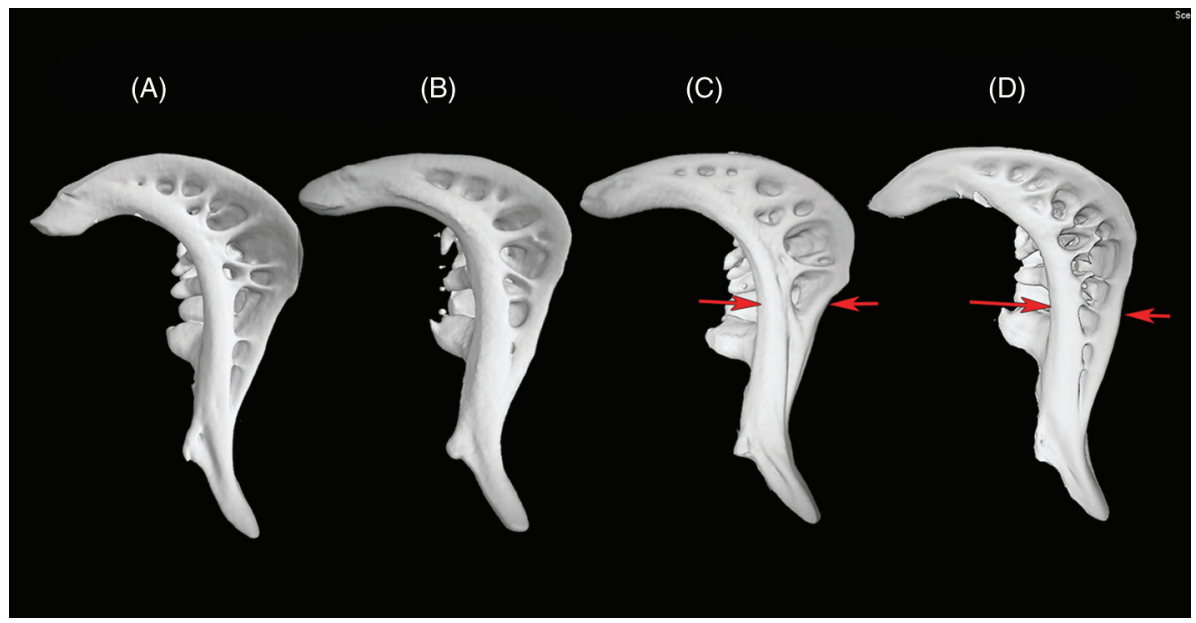

Appendix 2-5.- Pharyngeal teeth of the studied populations. The arrows show the width of the pharyngeal bone. A: Rifian population (Laou River). B: Sebou Basin (Ifrane River). C: Bou Regreg (Grou River). D: Luciobarbus ksibi (Kasab River).

Apéndice 2-5.- Dientes faríngeos de las diferentes poblaciones estudiadas. Entre flechas la anchura del hueso faríngeo. A: población del Rif (río Laou). B: Cuenca del Sebou (río lfrane). C: Cuenca del Bou Regreg (río Grou). D: Luciobarbus ksibi (río Kasab). 